Check for updates

Cite this: RSC Adv., 2018, 8, 21191

\title{
Schweinfurthins A-Q: isolation, synthesis, and biochemical properties
}

\author{
Dipesh S. Harmalkar, (D) ${ }^{a}$ Jyotirling R. Mali, ${ }^{a}$ Aneesh Sivaraman, ${ }^{a}$ Yongseok Choi $\mathbb{D}^{\mathrm{b}}$ \\ and Kyeong Lee (D)*a
}

Stilbene analogues have shown remarkable structural diversity constituting simple or tangled structures, which have attracted the synthetic as well as the medicinal chemistry communities. Schweinfurthins are a family of prenylated/geranylated/farnesylated stilbenes that are isolated from an African plant belonging to the Macaranga species. These compounds have displayed potency towards central nervous system, renal and breast cancer cell lines. Specifically, these compounds have been found to be potent and selective inhibitors of cell growth in the National Cancer Institute's 60 cell-line screen. In this review article, we described the isolation, synthesis, and biochemical properties of schweinfurthins.

Received 3rd April 2018

Accepted 21st May 2018

DOI: $10.1039 / \mathrm{c} 8 \mathrm{ra02872a}$

rsc.li/rsc-advances

Schweinfurthins are prenylated/geranylated/farnesylated

\section{Introduction}

The role of natural products in drug discovery has been phenomenal. The search for new lead compounds displaying potency and selectivity with the fewest adverse side effects has led to the synthesis of more and more new candidates for the treatment of various diseases. Natural products have been a significant resource of drug leads in the field of medicinal chemistry, and despite an upsurge in the use of combinatorial chemistry as a part of the lead development process, they still play a pivotal role owing to their diverse biochemical properties. $^{\mathbf{1 - 4}}$

Privileged structures have been widely used as effective templates in drug discovery. Stilbenes as such are a simple class of naturally occurring compounds that have a widespread distribution in nature (Fig. 1). Although their molecular backbone is made up of only a 1,2-diphenylethylene moiety, which exists as a trans- or cis-isomer, stilbenes have shown an immense array of different structural units. The stilbene moiety has been utilised as a starting source for the synthesis of new complex molecules.,

Resveratrol is a major constituent of the stilbene family that has received significant attention due to its anticancer activity. ${ }^{7-12}$ However, there are numerous analogues (naturally occurring, synthetic and semisynthetic) in this family with significant properties and applications. ${ }^{13-20}$ Additionally, several stilbene-based scaffolds have been approved for clinical use. For example, diethylstilboestrol and tamoxifen are used for the treatment of prostate cancer and metastatic breast cancer, respectively. ${ }^{21-25}$

${ }^{a}$ College of Pharmacy, Dongguk University-Seoul, Goyang, 10326, Republic of Korea. E-mail: kaylee@dongguk.edu

${ }^{b}$ Department of Biotechnology, Korea University, Seoul, 02841, Republic of Korea stilbenes that are isolated from numerous species of the plant genus Macaranga (Euphorbiaceae). There has been an increased interest in the schweinfurthin family because of their selective anti-proliferative activity against human cancer cells. The scarcity of natural schweinfurthins has enticed the evolution of the synthetic approach towards their total synthesis. This review provides details on the isolation, synthesis, and bioactivities of schweinfurthins. The difficulties overcome, along with the successful modification of synthetic strategies, are discussed in this review.

\section{Isolation}

Macaranga is a genus of tropical trees that belongs to the Euphorbiaceae family and is the only genus in the subtribe Macaranginae. It is one of the largest genera of the Euphorbiaceae, comprising approximately 300 different species generally found in Africa, Australasia, Asia, and various islands in the Indian and Pacific oceans. ${ }^{26}$ Until now, 17 naturally occurring schweinfurthins $(\mathrm{A}-\mathrm{Q})$ have been isolated from the Macaranga genus (Table 1). In addition, one of the closely related congeners, vedelianin, along with two synthetic schweinfurthin analogues, is discussed.

In the past few years, the most common species of the Macaranga genus, $M$. vedeliana, $M$. pleiostemona, $M$. indica, $M$. tanarius and M. schweinfurthii have been thoroughly studied. A number of different classes of compounds such as prenylated stilbenes, geranylated flavonols, prenylated flavanones, chromenoflavones and diterpenes have been isolated from this species. $^{33-36}$

Schweinfurthins A-D were first isolated by Beutler et al. as yellowish solids from a mixed $\mathrm{CH}_{2} \mathrm{Cl}_{2}-\mathrm{MeOH}$ extract of $M$. schweinfurthii. ${ }^{27,28}$ Another unexplored species of the Macaranga 




Fig. 1 Bioactive natural products with stilbene moiety.

genus, M. alnifolia, was highlighted by Yoder $e t$ al., who isolated four new prenylated stilbenes, schweinfurthins $\mathrm{E}-\mathrm{H}$, as pale yellow solids from an ethanolic extract of the fruit of $M$. alnifolia. ${ }^{29}$ Schweinfurthin $\mathrm{H}$ possesses a 2,2-dimethyldihydropyranol moiety, which was first observed in the schweinfurthin family. Klausmeyer et al. isolated two prenylated stilbenes, schweinfurthins I and $\mathrm{J}$ as yellow oils from the leaf of the $M$. schweinfurthii. ${ }^{30}$ Initially, Thoison et al. isolated vedelianin in 1991 from the leaves of M. vedeliana, which is closely related to the schweinfurthins. ${ }^{32}$ Later, Yoder et al. also isolated vedelianin along with schweinfurthins E-H from another Macaranga species, M. alnifolia. ${ }^{29}$

Recently, Péresse et al. isolated seven more schweinfurthins, $\mathrm{K}-\mathrm{Q}$, from M. tanarius. Among these seven newly reported natural products, only schweinfurthin $\mathrm{Q}$ has a hexahydroxanthene tricyclic core. Schweinfurthins $\mathrm{K}, \mathrm{L}$, and $\mathrm{M}$ possess a 2,2-dimethyldihydropyranol moiety. All of the compounds were isolated as orange oils from an ethanolic extract of the dried fruits of M. tanarius. ${ }^{31}$

\section{Synthesis}

Natural schweinfurthins possess a stilbene backbone with prenylated/geranylated/farnesylated moieties on any of the rings. Generally, the stilbene skeleton is synthesized using a Wittig or modified Wittig olefination, Heck, Suzuki, Stille or Sonogashira coupling reactions. In the case of the schweinfurthins, Horner-Wadsworth-Emmons (HWE) olefination has been utilised to selectively construct the trans-stilbene skeleton.

\subsection{Synthesis of hexahydroxanthene}

Hexahydroxanthene, a tricyclic moiety, is present in many schweinfurthins whose stereochemistry was not completely elucidated and hence, its synthesis was of the utmost important (Fig. 2). Previously, Mechoulam and Yagen have reported the cyclisation of geranyl olivetol under harsh reaction conditions using concentrated $\mathrm{H}_{2} \mathrm{SO}_{4}$ in nitromethane. ${ }^{37}$ In addition, an attempt was made to synthesize the hexahydroxanthene core from geranylated phenols by constructing A- and B-rings on the aromatic C-ring in a single step, which resulted in a poor yield, along with byproducts. ${ }^{38,39}$

3.1.1 The Treadwell et al. approach (2002). Treadwell et al. developed a convenient route for the synthesis of hexahydroxanthene. ${ }^{40}$ The presence of phenylthio and phenylselenyl groups at the alpha position, adjacent to the terminal cation on the geranyl chain, might provide substantial stability to the emerging carbocation. ${ }^{41,42}$ Based on previous studies, 29 was viewed as a key intermediate for constructing hexahydroxanthene..$^{43,44}$

The synthesis commenced with vanillin (21) to give benzaldehyde analogue $23 .^{45}$ The reduction of aldehyde 23 to alcohol 24 followed by protection with triethylsilyl ether afforded 25, 
Table 1 Structures of all schweinfurthins isolated from Macaranga species

Comp Name Structure

3

Schweinfurthin C

Schweinfurthin D

Schweinfurthin E

$6 a$

Schweinfurthin $\mathrm{F}$

Schweinfurthin G

8

Schweinfurthin $\mathrm{H}$

9

Schweinfurthin I<smiles>CC(C)=CCC/C(C)=C/Cc1c(O)cc(/C=C/c2cc(O)c3c(c2)C[C@@H]2O[C@@]3(C)C[C@H](O)[C@@H](O)C2(C)C)cc1O</smiles><smiles>COc1cc(/C=C/c2cc(O)c(C/C=C(\C)CCC=C(C)C)c(O)c2)cc2c1O[C@]1(C)C[C@@H](O)[C@@H](O)C(C)(C)[C@H]1C2</smiles>

Natural source

References<smiles>CC(C)=CCC/C(C)=C/Cc1cc(/C=C/c2cc(O)c(O)c(C/C=C(\C)CCC=C(C)C)c2)cc(O)c1O</smiles>

M. schweinfurthii

27<smiles>COc1cc(/C=C/c2cc(O)c(C/C=C(\C)CCCC(C)(C)O)c(O)c2)cc2c1O[C@]1(C)C[C@@H](O)[C@H](O)C(C)(C)[C@H]1C2</smiles>

M. schweinfurthii

28<smiles>COc1cc(/C=C/c2cc(O)c(CC=C(C)C)c(O)c2)cc2c1O[C@]1(C)C[C@@H](O)[C@H](O)C(C)(C)[C@H]1C2</smiles>

M. alnifolia

29

M. alnifolia

29<smiles>COc1cc(/C=C/c2cc(O)c(CC=C(C)C)c(O)c2)cc2c1O[C@]1(C)CC[C@@H](O)C(C)(C)[C@H]1C2</smiles>

M. alnifolia

29

M. alnifolia

29<smiles>COc1cc(/C=C/c2cc(O)c3c(c2)OC(C)(C)C(O)C3)cc2c1O[C@]1(C)C[C@@H](O)[C@H](O)C(C)(C)[C@H]1C2</smiles>

M. schweinfurthii
30 
Table 1 (Contd.)

\section{Comp Name}

Structure

Natural source

References

10

Schweinfurthin J

11

Schweinfurthin K

12

Schweinfurthin L

13

Schweinfurthin M

14

Schweinfurthin $\mathrm{N}$

16

Schweinfurthin $\mathrm{P}$

17

Schweinfurthin Q

3-Deoxyschweinfurthin A (3dSA)
$\mathrm{HO}$<smiles>CC(C)=CCC/C(C)=C/CC/C(C)=C/Cc1c(O)cc(/C=C/c2ccccc2)cc1O</smiles><smiles>CC(C)=CCC/C(C)=C/Cc1cc(/C=C/c2cc(O)c3c(c2)OC(C)(C)[C@@H](O)C3)cc(O)c1O</smiles><smiles>CC(C)=CCCC1(C)Oc2c(O)cc(/C=C/c3cc(O)c4c(c3)OC(C)(C)[C@@H](O)C4)cc2C[C@H]1O</smiles>

M. tanarius

31<smiles>C/C(=C\Cc1cc(/C=C/c2cc(O)c3c(c2)OC(C)(C)[C@@H](O)C3)cc(O)c1O)CCC(O)C(C)(C)O</smiles>

M. tanarius

31<smiles>CC(C)=CCc1c(O)cc(/C=C/c2cc(O)c(O)c(C/C=C(\C)CCC(O)C(C)(C)O)c2)cc1O</smiles>

M. tanarius

31<smiles>CCC(C)=CCCC(C)c1c(O)cc(C=Cc2ccc(O)c(O)c2)cc1O</smiles>

M. tanarius

31

31

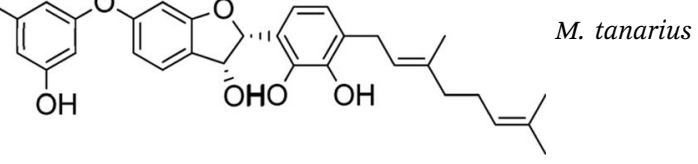

31<smiles>CC(C)=CCc1c(O)cc(/C=C/c2cc(O)c3c(c2)C[C@@]2(C)[C@H](O3)[C@H](O)C[C@@H](O)C2(C)C)cc1O</smiles><smiles>CC(C)=CCC/C(C)=C/Cc1c(O)cc(/C=C/c2cc(O)c3c(c2)C[C@@]2(C)[C@H](CC[C@@H](O)C2(C)C)O3)cc1O</smiles> 
Table 1 (Contd.)

\begin{tabular}{l} 
Comp Name \\
\hline $\begin{array}{l}\text { 3-Deoxyschweinfurthin B } \\
(3 \mathrm{dSB})\end{array} 20 \quad$ Structure \\
$(+)$-Vedelianin
\end{tabular}

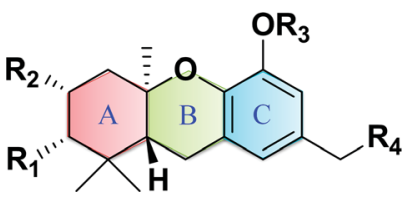

Fig. 2 Hexahydroxanthene moiety.

which upon reacting with geranyl bromide in the presence of $n$ BuLi furnished compound 26 in $74 \%$ yield. The $m$-CPBA epoxidation of compound 26 yielded the desired 6,7-epoxide 27 in $53 \%$ yield along with traces of 2,3-epoxide. Compound 27 reacted smoothly with a phenyl selenide anion to afford $\mathbf{2 8}$, which upon treatment with $0.5 \mathrm{M} \mathrm{HCl}$ (for the deprotection of the silyl ether) and subsequently with $1 \mathrm{M} \mathrm{HCl}$ (for the deprotection of MOM) gave hydroxyselenide 29 in $66 \%$ yield. The deprotection of both groups in a single step was unsuccessful, resulting in either incomplete deprotection or lower yields along with byproducts (Scheme 1).

To address the deprotection issue, Treadwell $e$ t al. developed an alternative synthetic route, as shown in Scheme 2 . Compound 30 obtained from vanillin was protected with TBS and selectively cleaved to obtain free phenol 32 using TBAF. Compound 32 was protected with ethyl vinyl ether (because silyl group migration from the phenolic oxygen to the adjacent orthocarbon was observed) to give the fully protected compound 33 . The geranylation of 33, followed by an acidic workup yielded

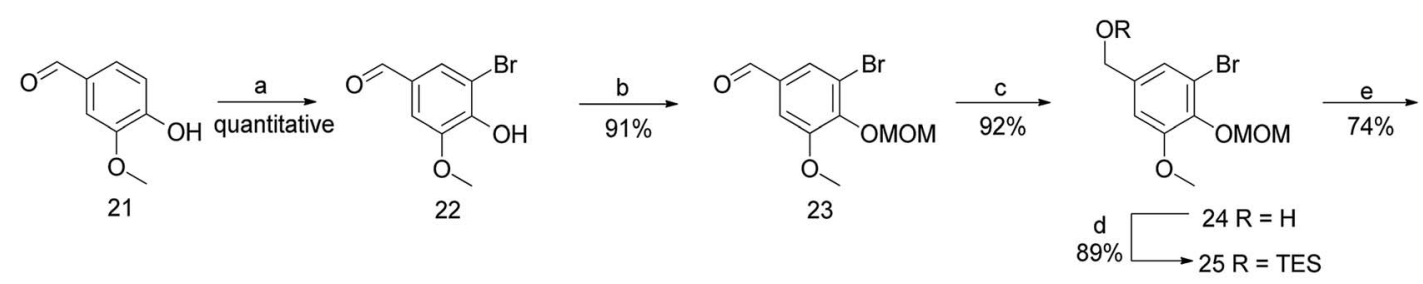

<smiles>COc1cc(CO)cc(C/C=C(\C)CCC([SeH]c2ccccc2)C(C)(C)O)c1O</smiles>

Scheme 1 Synthesis of cyclisation precursor hydroxyselenide (29). Reagents and conditions: (a) $\mathrm{Br}_{2}, \mathrm{CH}_{3} \mathrm{CO}_{2} \mathrm{H}, 25^{\circ} \mathrm{C} 0.5 \mathrm{~h}$; (b) $\mathrm{MOMCl}$, TBAl, $\mathrm{NaH}, \mathrm{DMF}$; (c) LAH, THF, $0{ }^{\circ} \mathrm{C}, 11 \mathrm{~min}$; (d) TESCl, imidazole, $\mathrm{CH}_{2} \mathrm{Cl}_{2}$; (e) $n$-BuLi, geranyl bromide, $\mathrm{THF},-78^{\circ} \mathrm{C}$; (f) $m-\mathrm{CPBA} \mathrm{CH} \mathrm{Cl}_{2},-30{ }^{\circ} \mathrm{C}$, 30 min; (g) $\mathrm{NaBH}_{4},(\mathrm{PhSe})_{2}, \mathrm{EtOH}$; (h) $0.5 \mathrm{M}$ or $1 \mathrm{M} \mathrm{HCl}, \mathrm{MeOH}$, reflux. 
<smiles>COc1cc(CO)cc(Br)c1O</smiles><smiles>[R20]c1c(Br)cc(C[SeH])cc1OC</smiles><smiles>[R5]Cc1cc(CC=C(C)CCC=C(C)C)c([R])c(OC)c1</smiles>

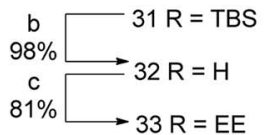

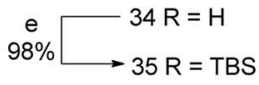<smiles>COc1cc(C[Se-])cc(C/C=C(\C)CCC2OC2(C)C)c1O[AsH3]</smiles><smiles>COc1cc(C[Se+])cc(C/C=C(\C)CCC([Se]c2ccccc2)C(C)(C)O)c1O[Ga+]</smiles><smiles>COc1cc(CO)cc(C/C=C(\C)CCC([Se]c2ccccc2)C(C)(C)O)c1O</smiles><smiles>COc1cc(CO)cc2c1O[C@]1(C)CC[C@H]([OH+]c3ccccc3)C(C)(C)[C@H]1C2</smiles>

Scheme 2 Synthesis of hexahydroxanthene (38). Reagents and conditions: (a) TBSCl, $\mathrm{CH}_{2} \mathrm{Cl}_{2}, 18 \mathrm{~h}$; (b) TBAF, THF, $1 \mathrm{~h}$; (c) pyridinium $p$-toluenesulphonate (PPTS), ethyl vinyl ether, $\mathrm{CH}_{2} \mathrm{Cl}_{2}, 40 \mathrm{~h}$; (d) $n$-BuLi, geranyl bromide, THF, $-78{ }^{\circ} \mathrm{C}$; (e) $\mathrm{TBSCl}_{1} \mathrm{CH}_{2} \mathrm{Cl}_{2}, 24 \mathrm{~h}$; (f) $m$ - $\mathrm{CPBA}, \mathrm{CH}_{2} \mathrm{Cl}_{2}$, $-30{ }^{\circ} \mathrm{C}, 30$ min; (g) $\mathrm{NaBH}_{4}$, (PhSe) $2, \mathrm{EtOH}, 48$ h; (h) TBAF, THF, 3 days; (i) TFA, $\mathrm{CH}_{2} \mathrm{Cl}_{2}, 24 \mathrm{~h}$.

compound 34, which was again protected with a silyl ether to afford 35 in 98\% yield. A synthetic route similar to Scheme 1 was followed to generate the cyclisation precursor $\alpha$-hydroxyselenide 29 from 35. The TFA-induced cyclisation of 29 afforded the tricyclic hexahydroxanthene core (38) in $43 \%$ yield. The formation of a single diastereomer was confirmed from NMR spectroscopy studies (Scheme 2).

3.1.2 The Neighbors et al. approach (2008). The firstgeneration synthesis of hexahydroxanthene 50a, involving a cascade cyclisation and asymmetric dihydroxylation, was low<smiles>[R20]Cc1cc(C/C=C(\C)CCC=C(C)C)c(OC)c(OC)c1</smiles>



<smiles>COc1cc(CO)cc2c1O[C@H]1CC[C@@H](O)C(C)(C)[C@H]1C2</smiles><smiles>C1CCCCC1</smiles><smiles>COc1cc(C=O)cc2c1O[C@]1(C)CC[C@@H](O)C(C)(C)C21C</smiles>
OR<smiles>COc1cc(C=O)cc2c1OC1(C)CC[C@H](O)C(C)(C)[C@H]1C2</smiles>

Scheme 3 Synthesis of hexahydroxanthene aldehyde (50a) via Sharpless dihydroxylation. Reagents and conditions: (a) $\mathrm{MOMCl} \mathrm{DIPEA}, \mathrm{CH}_{2} \mathrm{Cl}_{2}$, $10 \mathrm{~h}$ OR TBSCl, imidazole, $\mathrm{CH}_{2} \mathrm{Cl}_{2}, 16 \mathrm{~h}$; (b) geranyl bromide, $n$-BuLi, THF, $-78^{\circ} \mathrm{C}$; (c) AD-mix- $\alpha$ for $50 \mathrm{a}$ OR AD-mix- $\beta$ for $50 \mathrm{~b}, \mathrm{~K}_{2} \mathrm{Os} \mathrm{s}_{2} \mathrm{O}$ in $\mathrm{H}_{2} \mathrm{O} / \mathrm{t}-$ $\mathrm{BuOH}, \mathrm{CH}_{3} \mathrm{SO}_{2} \mathrm{NH}_{2}, 4 \mathrm{~h}$; (d) (1) $\mathrm{MsCl}_{2} \mathrm{NEt}_{3}, \mathrm{CH}_{2} \mathrm{Cl}_{2}, 2 \mathrm{~h}$, (2) $\mathrm{K}_{2} \mathrm{CO}_{3}, \mathrm{MeOH}, 20 \mathrm{~h}$; (e) TFA, $\mathrm{CH}_{2} \mathrm{Cl}_{2}, 1.5$ h; (f) TBAF, THF, 1.5 h; (g) $\mathrm{MnO}_{2}, \mathrm{CH}_{2} \mathrm{Cl}_{2}$. 


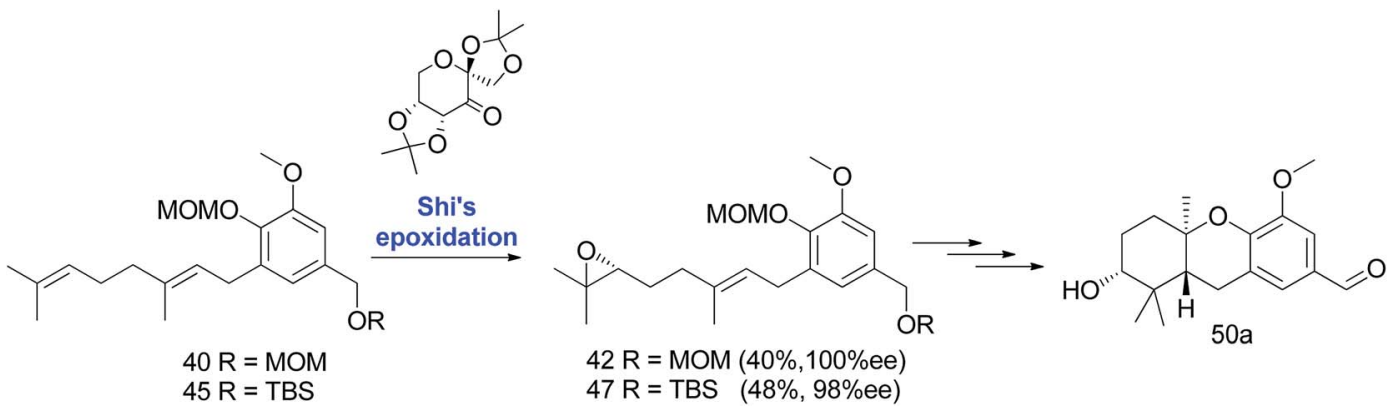

Scheme 4 Synthesis of hexahydroxanthene aldehyde (50a) via Shi's epoxidation. Reagents and conditions: Shi epoxidation diketal catalyst, buffer solution ( $2 \mathrm{M} \mathrm{K}_{2} \mathrm{CO}_{3}, 0.4 \mathrm{mM}$ EDTA), $\mathrm{H}_{2} \mathrm{O}_{2}, \mathrm{CH}_{3} \mathrm{CN}: \mathrm{CH}_{2} \mathrm{Cl}_{2}$ :EtOH.


Scheme 5 Synthesis of $R$-(6,7)-epoxygeranyl bromide (54) via Shi's epoxidation. Reagents and conditions: (a) Shi epoxidation diketal catalyst, buffer solution ( $2 \mathrm{M} \mathrm{K}_{2} \mathrm{CO}_{3}, 0.4 \mathrm{mM}$ EDTA), $\mathrm{H}_{2} \mathrm{O}_{2}, \mathrm{CH}_{3} \mathrm{CN}: \mathrm{CH}_{2} \mathrm{Cl}_{2}$ : EtOH, 3 days; (b) NaOMe, TBAl, $\mathrm{MeOH}, 2.5 \mathrm{~h}$; (c) (1) MsCl, $\mathrm{NEt}$, $\mathrm{CH}_{2} \mathrm{Cl}_{2}, 0.5 \mathrm{~h}$; (2) $\mathrm{LiBr}$ in THF, $2.5 \mathrm{~h}$; (d) $n$-BuLi, $44, \mathrm{CuCN}, \mathrm{THF},-78^{\circ} \mathrm{C}$.

a)

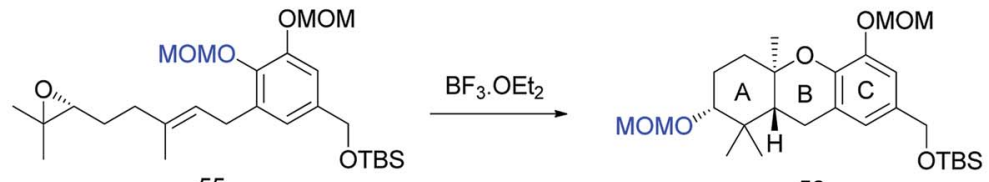

55

56<smiles>COc1cccc(OC)c1CC=C(C)CCC1OC1(C)C</smiles><smiles>COCc1ccc(OC)c2c1O[C@]1(C)CC[C@@H](O)C(C)C1C2</smiles>

57

58

b)

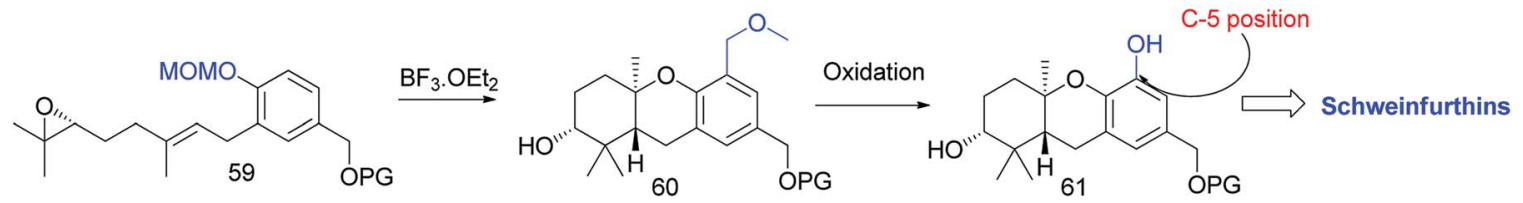

Scheme 6 Introduction of $-\mathrm{OH}$ on aromatic C-ring via tandem cascade cyclisation/aromatic substitution. (a) Migration of the MOM group on the $\mathrm{A}$ - and $\mathrm{C}$-rings during the $\mathrm{BF}_{3} \cdot \mathrm{OEt}_{2}$-mediated cyclisation step; (b) predicted route to introduce $-\mathrm{OH}$ onto the $\mathrm{C}$-ring via tandem cascade cyclisation/aromatic substitution. 
<smiles>COC(=O)c1ccc(O)cc1</smiles>

63 3<smiles></smiles>

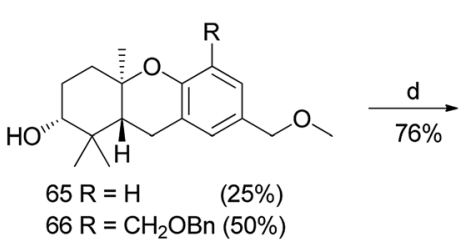<smiles>COCc1cc(CO)c2c(c1)C[C@H]1[C@H](C)C(C)(C)[C@@H](O)CC[C@@]1(C)O2</smiles>
67<smiles>COCc1cc(C=O)c2c(c1)C[C@@H]1[C@H](C)[C@@](C)(CC[C@H]1O)O2</smiles>
$66 \mathrm{R}=\mathrm{CH}_{2} \mathrm{OBn}(50 \%)$<smiles>COCc1cc(O)c2c(c1)C[C@]1(C)C(C)(C)[C@@H](O)CC[C@]1(C)O2</smiles><smiles>[2H][C@@]12Cc3cc(COC)cc(OC)c3O[C@]1(C)CC[C@@H](O)C2(C)C</smiles>

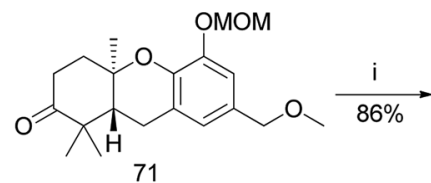<smiles>[Z16]C=C1C[C@]2(C)Oc3c(cc(COC)cc3OC)C[C@H]2C(C)(C)C(=O)/C1=C/C</smiles>

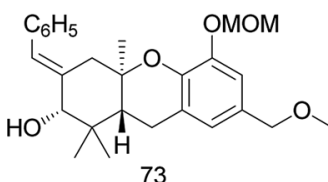

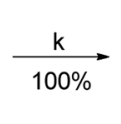

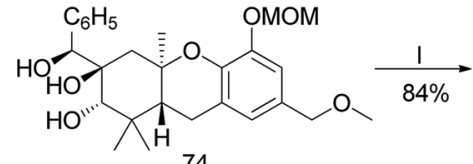

74<smiles>COCc1cc2c(c(OC)c1)O[C@@]1(C)CC(=O)[C@@H](O)C(C)([13CH3])[C@@H]1C2</smiles><smiles>COCc1cc2c(c(OC)c1)O[C@]1(C)C[C@H](O)[C@@H](O)C(C)(C)[C@]1(C)C2</smiles><smiles>[Z20]C1(C)Cc2cc(C=O)cc(OC)c2O[C@]2(C)C[C@H](O)[C@@H](O)C(C)(C)[C@]12C</smiles><smiles>COc1cc(C=O)cc2c1O[C@]1(C)C[C@H](OC)[C@@H](OC)C(C)(C)C21C=[13CH]</smiles>

Scheme 7 Synthesis of hexahydroxanthene aldehyde (78) by Topczewski et al. ${ }^{50}$ Reagents and conditions: (a) (1) $\mathrm{Br}_{2}, \mathrm{CH}_{2} \mathrm{Cl}_{2} ;(2) \mathrm{BOMCl}_{1} \mathrm{DIPEA}$, $\mathrm{CH}_{2} \mathrm{Cl}_{2}$; (3) $\mathrm{LiBH}_{4}$, ether; (4) Mel, NaH, THF, 5 h; (b) TMEDA, $n$-BuLi, Cul, (R)-6,7-epoxy-geranyl bromide 54, $\mathrm{Et}_{2} \mathrm{O},-8{ }^{\circ} \mathrm{C}_{\text {; }}(\mathrm{c}) \mathrm{BF}_{3} \cdot \mathrm{OEt}_{2}, \mathrm{CH}_{2} \mathrm{Cl}_{2}$, $-78^{\circ} \mathrm{C}, 8 \mathrm{~min}$; (d) $\mathrm{H}_{2}, 10 \% \mathrm{Pd} / \mathrm{C}, \mathrm{MeOH}, 23 \mathrm{~h}$; (e) $\mathrm{MnO}_{2} \cdot \mathrm{CH}_{2} \mathrm{Cl}_{2}, 20 \mathrm{~h}$; (f) (1) $\mathrm{m}-\mathrm{CPBA}, \mathrm{CH}_{2} \mathrm{Cl}_{2}, 2 \mathrm{~h}$; (2) $\mathrm{K}_{2} \mathrm{CO}_{3}, 20 \mathrm{~h}$; (g) MOMCl, DIPEA, CH $2 \mathrm{Cl}_{2} ; 2 \mathrm{~h}$; (h) catalytic TPAP, $\mathrm{NMO}, \mathrm{CH}_{2} \mathrm{Cl}_{2}, 26 \mathrm{~h}$; (i) $\mathrm{PhCHO}, \mathrm{KOH}, \mathrm{EtOH}, 25 \mathrm{~min}$; (j) $\mathrm{CeCl}_{3} \cdot 7 \mathrm{H}_{2} \mathrm{O}, \mathrm{NaBH}_{4}, \mathrm{MeOH}, 2 \mathrm{~h}$; (k) OsO,$t-\mathrm{BuOH}_{2} \mathrm{NMO}$, dioaxane: $\mathrm{H}_{2} \mathrm{O}, 17 \mathrm{~h}$; (l) $\mathrm{NalO}_{4}, \mathrm{CH}_{2} \mathrm{Cl}_{2}: \mathrm{H}_{2} \mathrm{O}, 24 \mathrm{~h}$; (m) NaBH$, \mathrm{MeOH}: \mathrm{THF}, 15$ min; (n) DDQ, $\mathrm{CH}_{2} \mathrm{Cl}_{2}: \mathrm{H}_{2} \mathrm{O}, 15$ min; (o) MOMCl, DIPEA, CH $2 \mathrm{Cl}_{2}, 5 \mathrm{~h}$.

in yield, with 16 steps required from vanillin $(10 \%$ overall yield). ${ }^{46}$ Considering the productivity, Neighbors et al. developed efficient synthetic routes for the preparation of a geranyl epoxide ring. ${ }^{47}$

3.1.2.1 A change in protective group strategy. The sharpless dihydroxylation of a MOM-protected compound 40 gave diol 41, which was transformed to epoxide $\mathbf{4 2}$ using a previously developed protocol. ${ }^{46}$ Acid catalysed cyclisation using TFA afforded compound 43; however, the deprotection of an intransigent benzylic MOM group was not observed as anticipated. Hence, the reaction sequence was repeated using TBS as a protecting group to obtain compound 48. Furthermore, the deprotection of TBS using TBAF gave benzyl alcohol 49, which upon benzylic oxidation using $\mathrm{MnO}_{2}$ cleanly afforded aldehyde 50a in 9\% overall yield from vanillin (enantiomer 50b was synthesized via the same route using $\mathrm{AD}-\mathrm{mix}-\beta)$ (Scheme 3). ${ }^{47}$

3.1.2.2. Epoxide generation via Shi epoxidation. In addition, Neighbors et al. used a conventional synthetic protocol to install the epoxide stereocenter. There has been a successful attempt of enantioselective epoxidation on the aromatic esters of isoprenoids. Owing to the previous work, the epoxidation of $\mathbf{4 0}$ and 45 using Shi epoxidation ${ }^{\mathbf{4 8 , 4 9}}$ yielded 42 and 47 in $40 \%$ and $48 \%$ yield ( $>98 \%$ ee), respectively. Shi epoxidation was found to be advantageous for reducing the number of required steps with an improved overall yield (Scheme 4$){ }^{47}$

3.1.2.3 Synthesis of $R$-(6,7)-epoxygeranyl bromide via Shi epoxidation. Neighbors et al. also developed an alternative route by eliminating the epoxidation step in the primary synthetic 




79<smiles>COC(=O)c1cc(OC)cc(OC)c1</smiles>

80

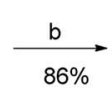

$86 \%$

(1)

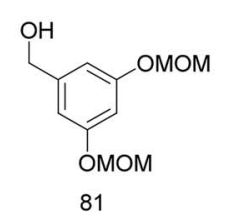

81

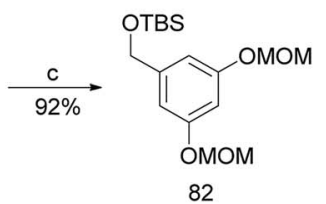

82
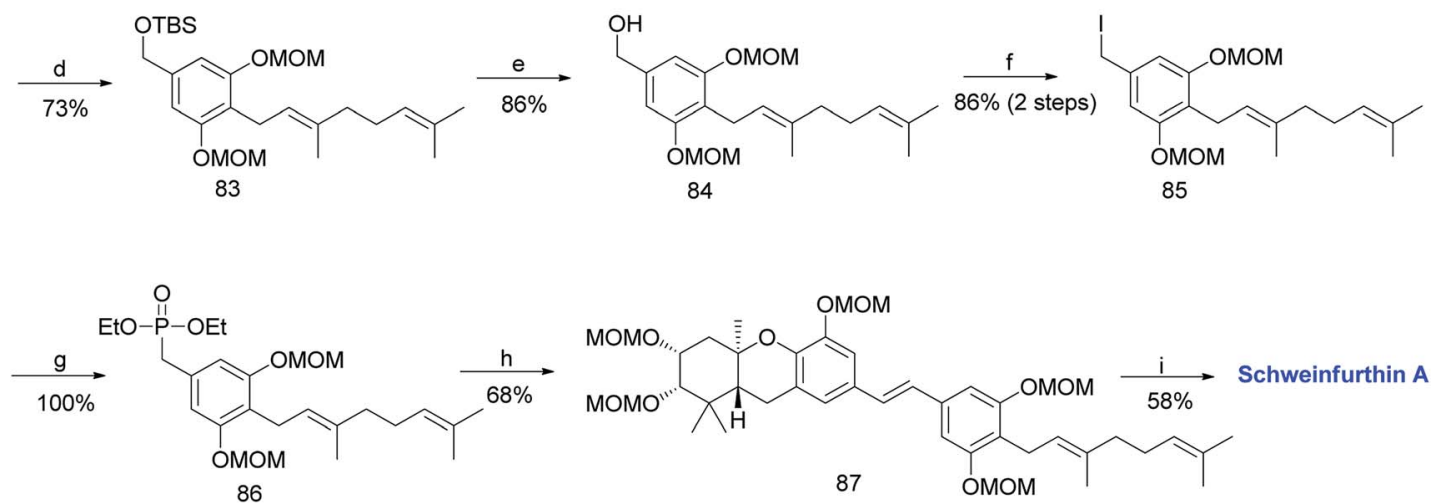

Scheme 8 Synthesis of schweinfurthin A by Topczewski et al. ${ }^{50}$ Reagents and conditions: (a) MOMCl, NaH, DMF, 4 h; (b) LAH, THF, 30 min; (c) TBSCl, imidazole, $\mathrm{CH}_{2} \mathrm{Cl}_{2}, 12 \mathrm{~h}$; (d) $n$-BuLi, TMEDA, CuCN, geranyl bromide, THF, $-78^{\circ} \mathrm{C}$; (e) TBAF, $\mathrm{THF}, 3 \mathrm{~h}$; (f) (1) $\mathrm{MsCl}^{\mathrm{NEEt}}, \mathrm{CH}_{2} \mathrm{Cl}_{2}, 1 \mathrm{~h}$; (2) $\mathrm{Nal}$, acetone, 22 h; (g) P(OEt) 3 , reflux, 2.5 h; (h) (1) DIPEA, $n$-BuLi, aldehyde 78, THF, 2 h (little progress in reaction); (2) KHMDS, 2 h; (i) $p$-TsOH, MeOH.

route and synthesized $R$-(6,7)-epoxygeranyl bromide $\mathbf{5 4}$ by Shi epoxidation. The treatment of epoxybromide $\mathbf{5 4}$ with aryl bromide 44 using lithium-halogen exchange gave 47 in $67 \%$ yield, which could be converted to aldehyde 50a (Scheme 5). ${ }^{47}$

\subsection{Synthesis of schweinfurthin A (2011)}

Topczewski et al. reported the total synthesis of schweinfurthin A (1), which is a potent compound in this family. ${ }^{50}$ Previous studies have reported the migration of the MOM group to the hydroxyl group of the A-ring during cascade cyclization (56). In addition, an electrophilic aromatic substitution occurs forming a new carbon-carbon bond by migration of the MOM group to an adjacent aromatic C-ring (58) (Scheme 6a)..$^{51}$ Hence, it was envisaged that the boron trifluoride etherate $\left(\mathrm{BF}_{3} \cdot \mathrm{OEt}_{2}\right)$-mediated cyclisation ${ }^{52}$ on MOM-protected epoxide 59 may afford hexahydroxanthene $\mathbf{6 0}$ with the MOM group moving to the C-5 position, from which intermediate $\mathbf{6 1}$ with a phenolic functionality could be obtained by oxidation (Scheme $6 \mathrm{~b}$ ).

Accordingly, a compound possessing an $(R)$-6,7-epoxygeranyl chain (64) was synthesized from 4-hydroxybenzoate (62) in 5 steps ( $93 \%$ ee). The $\mathrm{BF}_{3} \cdot \mathrm{OEt}_{2}$-mediated cascade cyclisation gave an inseparable mixture of $\mathbf{6 5}$ and $\mathbf{6 6}$ in $25 \%$ and $50 \%$ yield, respectively. А ВОМ acetal was chosen as the protecting group because it could be selectively deprotected by hydrogenolysis after being transferred to the C-5 position of the aromatic Cring. Compounds 65 and 66 were separated by selective hydrogenolysis to afford benzylic alcohol 67 in $76 \%$ yield. Furthermore, the chemo-selective benzylic oxidation of $\mathbf{6 7}$ gave the corresponding aldehyde 68, which upon subsequent BaeyerVilliger oxidation with $m$-CPBA and hydrolysis of formate yielded compound 69 in $98 \%$ yield. The $-\mathrm{OH}$ functionality was successfully introduced at the C-5 position of the aromatic Cring, and protection with MOM gave 70 in 89\% yield (Scheme 7).
The oxidation of hexahydroxanthene $\mathbf{7 0}$ under Ley's conditions gave ketone $\mathbf{7 1}$, which was subjected to aldol condensation with benzaldehyde to give enone $\mathbf{7 2}$, followed by Luche reduction to afford alcohol $\mathbf{7 3}$. Compound $\mathbf{7 3}$ was subjected to Upjohn dihydroxylation to give triol $\mathbf{7 4}$, which upon glycolytic cleavage in the presence of $\mathrm{NaIO}_{4}$ yielded ketone 75. The diastereoselective reduction of $\mathbf{7 5}$ using $\mathrm{NaBH}_{4}$ gave diol 76, and subsequent DDQ oxidation of the methyl ether on the aromatic C-ring gave the intermediate aldehyde 77 . The obtained aldehyde was protected with the MOM group to give aldehyde 78 in $74 \%$ yield (Scheme 7 ).

The required phosphonate ester $\mathbf{8 6}$ was synthesized, as depicted in Scheme $8{ }^{53,59}$ The synthesis began with the MOMprotection of commercially available phenolic ester 79 to obtain compound $\mathbf{8 0}$, followed by reduction to give benzyl alcohol 81. Furthermore, compound 81 was protected with a TBS group to afford $\mathbf{8 2}$. The metalation of $\mathbf{8 2}$ with $n$-BuLi and TMEDA in the presence of copper cyanide (CuCN), followed by a subsequent reaction with geranyl bromide gave 83. The TBS deprotection of compound 83 using TBAF yielded benzylic alcohol 84 in $86 \%$ yield, which was sequentially converted to phosphonate ester $\mathbf{8 6}$ by treatment with methanesulfonyl chloride ( $\mathrm{MsCl})$, followed by iodination, and subjecting it to the Arbuzov reaction with $\mathrm{P}(\mathrm{OEt})_{3}$. The phosphonate ester 86 was condensed with MOM-protected aldehyde 78 using an HWE olefination in the presence of KHMDS as a base to give protected $(E)$-stilbene 87. Finally, deprotection of the MOM groups under acidic conditions afforded schweinfurthin A (1) in 58\% yield (Scheme 8).

\subsection{Synthesis of schweinfurthin B (2009)}

Topczewski et al. reported the synthesis of schweinfurthin B (2) by eliminating the established desilylation/oxidation 
<smiles>COc1cc(CO)cc(Br)c1OC</smiles>

24<smiles>COCc1cc(Br)c(OC)c(OC)c1</smiles>

88

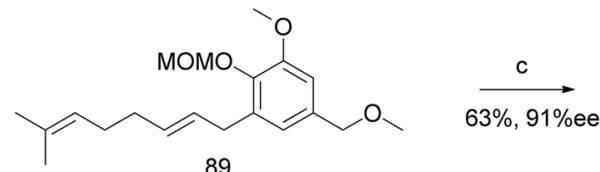

89<smiles>COCc1cc(COC)c(OC)c(OC)c1</smiles>

<smiles>C/C=C1\C[C@]2(C)Oc3c(cc(COC)cc3OC)C[C@]2(C)C(C)(C)[C@@H]1O</smiles>

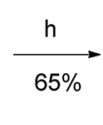<smiles>C/C=C1/C[C@@]2(C)Oc3c(cc(COC)cc3OC)CC2(C)C(C)(C)[C@@H](OC)/C1=C/C</smiles><smiles>COCc1cc2c(c(OC)c1)O[C@]1(C)CC(=O)[C@H](OC)C(C)(C)[C@H]1C2</smiles>

96<smiles>COCc1cc2c(c(OC)c1)O[C@@]1(C)C[C@H](O)[C@@H](OC(C)C)C(C)(C)[C@@]1(C)C2</smiles><smiles>COc1cc(C=O)cc2c1O[C@]1(C)C[C@H](O)[C@@H](OC)C(C)(C)[C@H]1C2</smiles><smiles>C/C=C/CC/C(C)=C/Cc1c(OC)cc(/C=C/c2cc3c(c(OC)c2)O[C@H]2C[C@H](O)[C@H](OC)C(C)(C)[C@]2(C)C3)cc1OC</smiles>

Scheme 9 Synthesis of schweinfurthin B by Topczewski et al. ${ }^{54}$ Reagents and conditions: (a) NaH, Mel, THF, 3 h; (b) $n$-BuLi, geranyl bromide, $\mathrm{THF},-78{ }^{\circ} \mathrm{C}$; (c) Shi epoxidation diketal catalyst, buffer solution (2 $\mathrm{M} \mathrm{K}_{2} \mathrm{CO}_{3}, 0.4 \mathrm{mM}$ EDTA), $\mathrm{H}_{2} \mathrm{O}_{2}, \mathrm{CH}_{3} \mathrm{CN}_{2} \mathrm{CH}_{2} \mathrm{Cl}_{2}: \mathrm{EtOH}_{1}, 10 \mathrm{~h}$; (d) $\mathrm{BF}_{3} \cdot \mathrm{OEt}_{2}$, $\mathrm{CH}_{2} \mathrm{Cl}_{2},-78{ }^{\circ} \mathrm{C}, 7 \mathrm{~min}$; (e) NMO, TPAP, $\mathrm{CH}_{2} \mathrm{Cl}_{2}, 18.5 \mathrm{~h}$; (f) benzaldehyde, $\mathrm{KOH}$, EtOH, 2 h. (g) $\mathrm{CeCl}_{3} \cdot 7 \mathrm{H}_{2} \mathrm{O}, \mathrm{NaBH}_{4}, \mathrm{CH}_{3} \mathrm{OH}, 20 \mathrm{~min}$; (h) $\mathrm{MOMCl}$, DIPEA, $\mathrm{CH}_{2} \mathrm{Cl}_{2}, 15 \mathrm{~h}$; (i) $\mathrm{KMnO}_{4}, \mathrm{NaHCO}_{3}$, acetone, 20 h; (j) $\mathrm{NaBH}_{4}, \mathrm{CH}_{3} \mathrm{OH}, 10$ min; (k) DDQ, $\mathrm{CH}_{2} \mathrm{Cl}_{2}: \mathrm{H}_{2} \mathrm{O}, 80$ min; (l) NaH, phosphonate ester 86 , 15-crown-5, THF; (m) p-TsOH, MeOH.

sequence. ${ }^{54}$ Benzyl alcohol 24 was protected with a benzyl methyl ether and converted to tricyclic compound 91 via Shi epoxidation followed by a $\mathrm{BF}_{3} \cdot \mathrm{OEt}_{2}$-mediated cascade cyclisation. The oxidation of compound 91 under Ley's conditions afforded ketone 92. The aldol condensation of compound 92 with benzaldehyde gave enone $\mathbf{9 3}$, which upon treatment with $\mathrm{OsO}_{4} / \mathrm{NaIO}_{4}$ resulted in an undesirable acetal compound; however, the reduction under Luche conditions afforded the required alcohol 94. The configuration was evident from NOESY correlations. The oxidation of MOM-protected compound $\mathbf{9 5}$ using excess $\mathrm{KMnO}_{4}$ gave ketone 96, and subsequent $\mathrm{NaBH}_{4}$ reduction yielded secondary alcohol $\mathbf{9 7}$, which upon DDQ oxidation of the methyl ether gave aldehyde 98 in excellent yield. The HWE olefination of phosphonate ester 86 with aldehyde $\mathbf{9 8}$ yielded $(E)$-stilbene $\mathbf{9 9}$, which upon deprotection of the MOM groups gave schweinfurthin B (2) in $55 \%$ yield (Scheme 9). ${ }^{54}$

\subsection{Synthesis of schweinfurthin C (1999)}

The first total synthesis of schweinfurthin C (3) was reported in 1999 by Treadwell et al. ${ }^{53}$ TES-protected benzylic alcohol 102 was synthesized from the known aldehyde $\mathbf{1 0 0}$, readily prepared from vanillin..$^{5-57}$ Furthermore, a geranyl moiety was installed via lithium-halogen exchange using $n$-BuLi and geranyl bromide to give 103, which upon deprotection followed by PDC oxidation afforded aldehyde 105 in $96 \%$ yield. The HWE olefination of phosphonate ester $\mathbf{8 6}$ with aldehyde 105 selectively gave $(E)$-stilbene 106, and deprotection of the MOM groups afforded schweinfurthin C (3) in 51\% yield (Scheme 10).

\subsection{Synthesis of schweinfurthin E (2009)}

Topczewski et al. reported the synthesis of schweinfurthin E (5) using the same synthetic route as schweinfurthin B. ${ }^{54} \mathrm{~A}$ phosphonate ester $\mathbf{1 0 8}$ was synthesized using the reported method. ${ }^{58,59}$ A prenyl group was introduced by directed ortho- 
<smiles>[R]Cc1cc(C/C=C(\C)CC/C=C(/C)CCCCCC)c(OC)c(OC)c1</smiles>



Scheme 10 Synthesis of schweinfurthin $\mathrm{C}$ by Treadwell et al. ${ }^{53}$ Reagents and conditions: (a) $\mathrm{LAH}, \mathrm{Et}_{2} \mathrm{O}, 0{ }^{\circ} \mathrm{C}, 10 \mathrm{~min} ;(\mathrm{b}) \mathrm{TESCl}, \mathrm{CH} \mathrm{Cl}_{2}, 22 \mathrm{~h}$; (c) n-BuLi, geranyl bromide, $\mathrm{Et}_{2} \mathrm{O},-78^{\circ} \mathrm{C}$; (d) TBAF, THF, $5 \mathrm{~h}$; (e) PDC, $\mathrm{CH}_{2} \mathrm{Cl}_{2}, 2.5 \mathrm{~h}$; (f) phosphonate ester 86, $\mathrm{NaH}$, THF, 30 min; (g) $3 \mathrm{M} \mathrm{HCl}, \mathrm{MeOH}$, reflux, $24 \mathrm{~min}$.

metalation on the known benzylic alcohol $\mathbf{8 1}$ to afford compound 107. Compound $\mathbf{1 0 7}$ was sequentially converted to the desired phosphonate ester 108, as depicted in Scheme 11. Phosphonate ester 108 and aldehyde 98 were condensed using HWE olefination to give protected $(E)$-stilbene 109, which was then deprotected under acidic conditions to obtain schweinfurthin E (5) in $81 \%$ yield (Scheme 11).

\subsection{Synthesis of schweinfurthin $\mathbf{F}(2007)$}

Mente et al. reported the synthesis of two enantiomers of schweinfurthin $\mathrm{F}$ in $2007 .{ }^{58}$ Having established the synthetic route for aldehydes 50a,b and phosphonate ester 108, HWE olefination followed by the acid-catalysed removal of the MOM groups afforded both the enantiomers schweinfurthin $\mathrm{F}$ $[(R, R, R)$-enantiomer $\mathbf{6 a}$ (69\% yield) and $(S, S, S)$-enantiomer $\mathbf{6 b}$ $(53 \%$ yield)]. Optical rotations and bioassay results indicated the formation of the $\mathbf{6 a}$ enantiomer, which is the natural form of schweinfurthin F (Scheme 12).

\subsection{Synthesis of schweinfurthin $G$ (2008)}

Mente et al. reported the synthesis of schweinfurthin G (7) via an efficient cascade cyclisation using $\mathrm{BF}_{3} \cdot \mathrm{Et}_{2} \mathrm{O}$ as a Lewis acid. ${ }^{52}$ Initially, several Lewis acids were examined to cyclize epoxide 47, such as $\mathrm{Ti}(\mathrm{OiPr})_{4}, \mathrm{TiCl}_{4}, \mathrm{SnCl}_{4}, \mathrm{MeAlCl}_{2}, \mathrm{In}(\mathrm{OTf})_{3}$ and $\mathrm{BF}_{3^{-}}$ $\cdot \mathrm{Et}_{2} \mathrm{O}$. The best result was obtained with the use of $\mathrm{BF}_{3} \cdot \mathrm{Et}_{2} \mathrm{O}$, and the cascade cyclisation was convenient and productive at larger scales. Using this approach, hexahydroxanthene was obtained in excellent yield $(\sim 75 \%)$ compared with the protic acid-catalysed cyclisation $(30-40 \%){ }^{60-64}$

The MOM-protected aldehyde $\mathbf{1 0 0}$ was sequentially converted to epoxide $55 \mathrm{via}$ Shi epoxidation. The cascade cyclisation was achieved by reacting with $\mathrm{BF}_{3} \cdot \mathrm{Et}_{2} \mathrm{O}$ to give hexahydroxanthenes 113 and 56 in $52 \%$ and $30 \%$ yield, respectively. The formation of the A-ring MOM ether $\mathbf{5 6}$ was observed due to the reaction of the $\mathrm{CH}_{3} \mathrm{OCH}_{2}{ }^{+}$cation with the nucleophilic oxygen of the C-2 hydroxyl group during cyclisation. The deprotection of TBS using TBAF gave compound 114, which upon benzylic<smiles>COc1cc(CO)cc(OC)c1</smiles>

81<smiles>COc1cc(CO)cc(OC)c1CC=C(C)C</smiles>

107
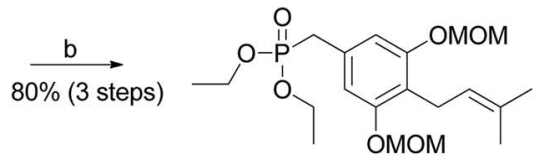

108



Scheme 11 Synthesis of schweinfurthin E by Topczewski et al. ${ }^{54}$ Reagents and conditions: (a) $n$-BuLi, TMEDA, CuBr.DMS, prenyl bromide,

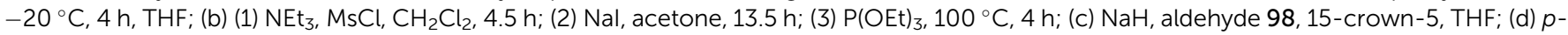
$\mathrm{TsOH}, \mathrm{MeOH}$. 


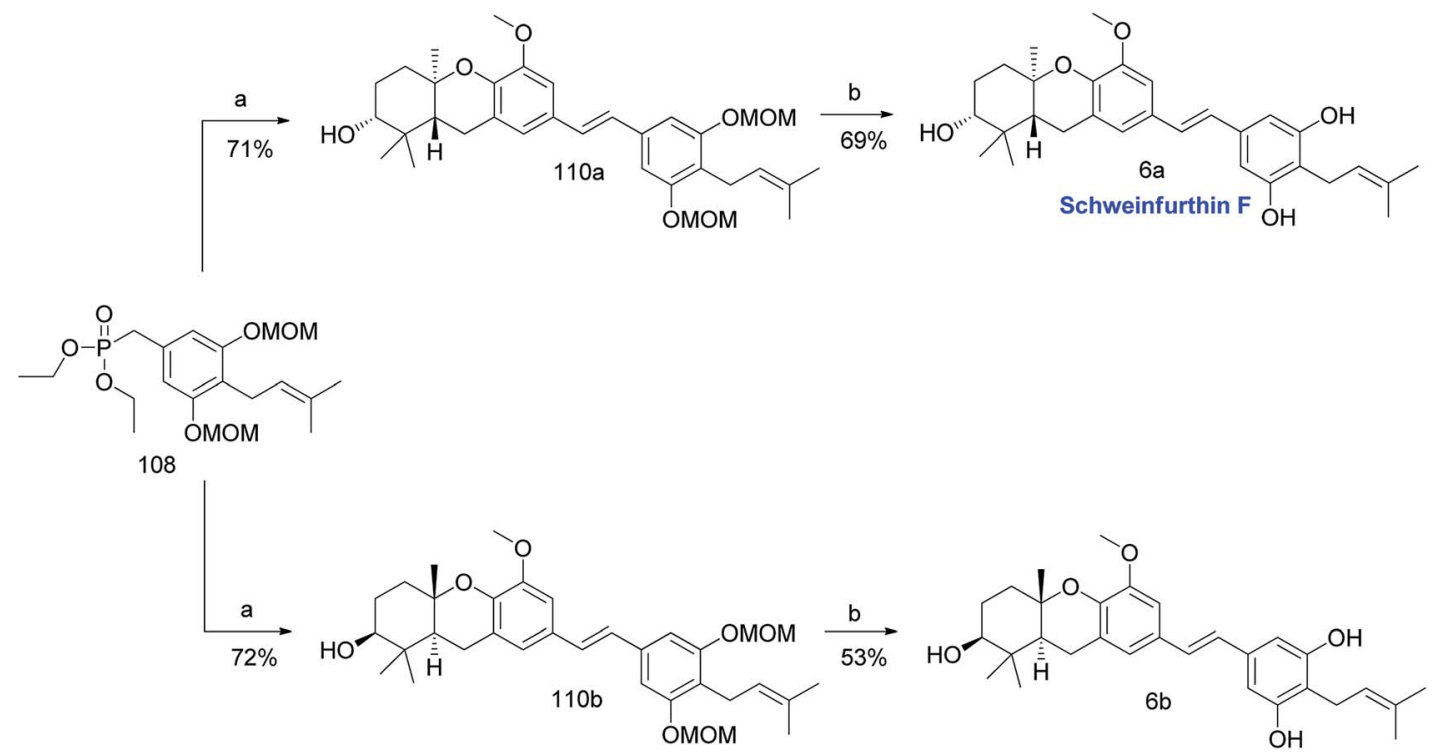

Scheme 12 Synthesis of schweinfurthin F by Mente et al. ${ }^{58}$ Reagents and conditions: (a) $50 \mathrm{a}$ or $50 \mathrm{~b}, \mathrm{NaH}, 15-\mathrm{crown}-5, \mathrm{THF}, 0{ }^{\circ} \mathrm{C}$ to rt, $24 \mathrm{~h}$; (b) $\mathrm{CSA}, \mathrm{MeOH}$, rt for $16 \mathrm{~h}, 55^{\circ} \mathrm{C}$ for $3.5 \mathrm{~h}$.

oxidation using $\mathrm{MnO}_{2}$ furnished aldehyde 115 in excellent yield. The HWE olefination of phosphonate ester 108 with aldehyde 115 yielded $(E)$-stilbene 116, which upon MOM-deprotection gave schweinfurthin G (7) in 57\% yield (Scheme 13).

\subsection{Synthesis of schweinfurthin $\mathbf{J}$ (2012)}

Argade et al. reported the synthesis of farnesylated stilbene schweinfurthin J (10) ${ }^{65}$ The required coupling partners for Heck (118), Stille (120), Suzuki (122), and Sonogashira (119) coupling reactions were synthesized from aldehyde $\mathbf{1 1 7}$, as outlined in
Scheme 14. A standard Wittig reaction with MOM-protected aldehyde 117 gave alkene 118 in 65\% yield. The treatment of aldehyde 117 with the Bestmann-Ohira reagent gave 119, and followed by radical hydrostannation yielded stannane $\mathbf{1 2 0}$. Additionally, Takai olefination of aldehyde $\mathbf{1 1 7}$ afforded vinyl iodide 121, which was subsequently converted to pinacolborane 122 in $80 \%$ yield (Scheme 14).

The phenolic compound $\mathbf{1 2 3}$ was alkylated using farnesyl bromide to give 124, followed by Claisen rearrangement to give $p$-farnesylated compound 125. The free phenolic group was<smiles>COc1cc(C=O)cc(Br)c1OCC(C)C</smiles>



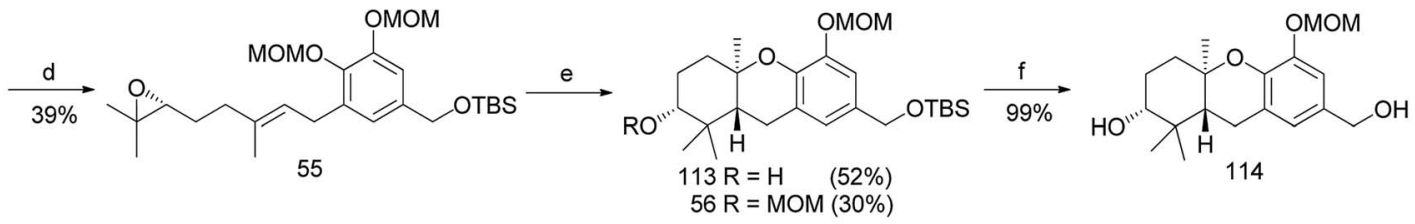



Scheme 13 Synthesis of schweinfurthin $\mathrm{G}$ by Mente et al. ${ }^{52}$ Reagents and conditions: (a) $\mathrm{NaBH}_{4}, \mathrm{THF}$; (b) TBSCl, imidazole, $\mathrm{CH}_{2} \mathrm{Cl}_{2}, 15$ h; (c) $n$ -

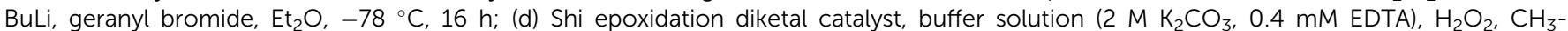
$\mathrm{CN}: \mathrm{CH}_{2} \mathrm{Cl}_{2}: \mathrm{EtOH}, 22 \mathrm{~h}$; (e) $\mathrm{BF}_{3} \cdot \mathrm{Et}_{2} \mathrm{O}, \mathrm{CH}_{2} \mathrm{Cl}_{2}, 3.5 \mathrm{~min}$; (f) TBAF, THF; (g) $\mathrm{MnO}_{2}, \mathrm{CH}_{2} \mathrm{Cl}_{2}, 16.5 \mathrm{~h}$; (h) NaH, phosphonate ester 108, 15-crown-5, THF; (i) $p-\mathrm{TsOH}, \mathrm{MeOH}$. 


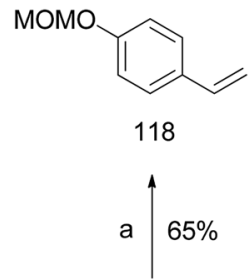<smiles>COc1ccc(C=O)cc1</smiles>

117



119

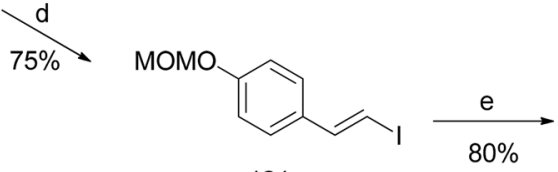

121

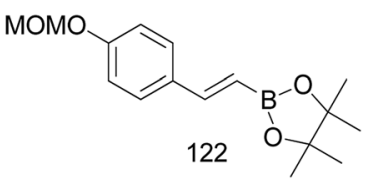

Scheme 14 Synthesis of intermediates 118-120 and 122. Reagents and conditions: (a) $n$-BuLi, MePPh 3 , THF, 24 h; (b) Bestmann-Ohira reagent, $\mathrm{K}_{2} \mathrm{CO}_{3}, \mathrm{MeOH}, 24 \mathrm{~h}$; (c) $n-\mathrm{Bu}_{3} \mathrm{SnH}, \mathrm{AIBN}, 80^{\circ} \mathrm{C}, 12 \mathrm{~h}$; (d) $\mathrm{CrCl}_{2}, \mathrm{CHI}_{3}$, dioxane:THF, $0{ }^{\circ} \mathrm{C}, 2 \mathrm{~h}$; (e) $t$-BuLi, boronate, $\mathrm{THF},-78{ }^{\circ} \mathrm{C}, 2 \mathrm{~h}$.

converted to a triflyloxy-leaving group, resulting in the formation of intermediate 126 in modest yield, which underwent Heck, Stille, or Suzuki coupling reactions with the respective coupling partners to yield protected $(E)$-stilbene 127 (62-67\% yield). Finally, the acid-catalysed deprotection of 127 afforded schweinfurthin J (10) in 57\% yield. Alternatively, the Sonogashira coupling of 119 and triflate 126 yielded alkyne 128, which upon reduction gave cis-stilbene 129 using $\mathrm{Pd}(\mathrm{OAc})_{2}$ in the presence of $\mathrm{KOH}$ in dimethylformamide (DMF). The isomerization of cis-stilbene 129 to trans-stilbene 127 (85\% yield) was achieved using $\mathrm{Pd}(\mathrm{MeCN})_{2} \mathrm{Cl}_{2}$ as a catalyst (Scheme 15).

\subsection{Synthesis of 3-deoxyschweinfurthin A (3dSA) (2008)}

Mente et al. reported the synthesis of 3dSA (18) from aldehyde 115 and phosphonate ester 86, similar to that of schweinfurthin $\mathrm{G}$ (Scheme 16). ${ }^{52}$

Additionally, Mente et al. utilised the byproduct compound 56 and transformed it into the phosphonate ester 132. The MOM-protected geranyl aldehyde $\mathbf{1 3 3}$ was synthesized by according to a reported procedure ${ }^{66}$ and was condensed with phosphonate ester 132 using an HWE reaction to give $(E)$-stilbene 134. Finally, deprotection of the MOM groups under acidic conditions gave $3 \mathrm{dSA}(\mathbf{1 8})$ in $52 \%$ yield (Scheme 17$).{ }^{52}$<smiles>COc1cc(OC)cc(OC)c1</smiles>

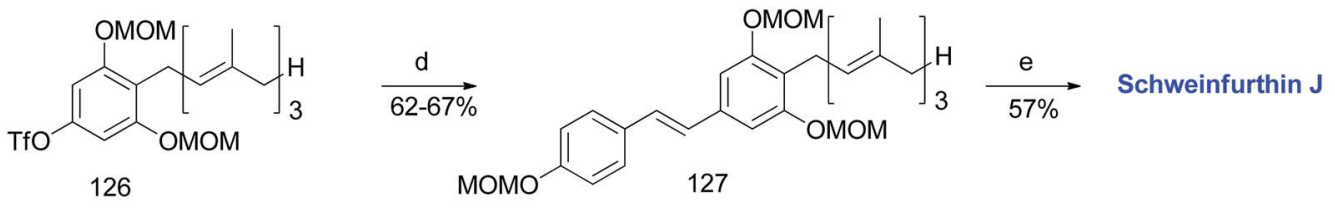<smiles>COc1ccc(/C=C/c2cc(OC)c(/C(C)=C/C(C)=C(\C)CC(C)C)c(OC)c2)cc1</smiles>

Scheme 15 Synthesis of schweinfurthin J by Argade et al. ${ }^{65}$ Reagents and conditions: (a) $\mathrm{K}_{2} \mathrm{CO}_{3}$, farnesyl bromide, DMF, $12 \mathrm{~h}$; (b) DMA, $200{ }^{\circ} \mathrm{C}$, $3 \mathrm{~h}$; (c) $\mathrm{Tf}_{2} \mathrm{O}$, pyridine, $\mathrm{CH}_{2} \mathrm{Cl}_{2},-20{ }^{\circ} \mathrm{C}, 2 \mathrm{~h}$; (d) (1) Heck coupling: 118, $\mathrm{Pd}(\mathrm{OAc})_{2}, \mathrm{Ph}_{3} \mathrm{P}, \mathrm{Et}{ }_{3} \mathrm{~N}, \mathrm{MeCN}, 85^{\circ} \mathrm{C}, 24$ h, $63 \%$; (2) Stille coupling: 120 , $\mathrm{Pd}\left(\mathrm{PPh}_{3}\right)_{4}, \mathrm{LiCl}, \mathrm{DMF}, 120^{\circ} \mathrm{C}, 8 \mathrm{~h}, 67 \%$; (3) Suzuki coupling: 122, $\mathrm{Pd}\left(\mathrm{PPh}_{3}\right)_{4}, \mathrm{Na}_{2} \mathrm{CO}_{3}$, dioxane: $\mathrm{H}_{2} \mathrm{O}, 90{ }^{\circ} \mathrm{C}, 8 \mathrm{~h}, 66 \%$; (e) $\mathrm{CSA}, \mathrm{MeOH} ; 12 \mathrm{~h}$; (f) Sonogashira coupling: 119, $\mathrm{PdCl}_{2}\left(\mathrm{PPh}_{3}\right)_{2}, \mathrm{Cul}, \mathrm{TBAl}, \mathrm{DMF}: \mathrm{Et}_{3} \mathrm{~N}, 70{ }^{\circ} \mathrm{C}, 1.5 \mathrm{~h}$; (g) $\mathrm{Pd}(\mathrm{OAc})_{2}, \mathrm{KOH}, \mathrm{DMF} ;(\mathrm{h}) \mathrm{Pd}\left(\mathrm{MeCN}_{2} \mathrm{Cl}_{2}, \mathrm{CH}_{2} \mathrm{Cl}, 25{ }^{\circ} \mathrm{C}, 12 \mathrm{~h}\right.$. 
<smiles>COc1cc(C=O)cc2c1O[C@]1(C)CC[C@@H](O)C(C)(C)[C@]1(C)C2</smiles><smiles>COc1cc(/C=C/c2cc3c(c(OC)c2)[C@]2(C)CCC(C)(C)[C@@H](C)C(C)(C3)O2)cc(OC)c1C/C=C(\C)CCC=C(C)C</smiles>

3dSA

Scheme 16 Synthesis of 3-deoxyschweinfurthin A (3dSA) by Mente et al. ${ }^{52}$ Reagents and conditions: (a) NaH, phosphonate ester 86, 15-crown-5, $\mathrm{THF}$; (b) $\mathrm{p}-\mathrm{TsOH}, \mathrm{MeOH}$.

\subsection{Synthesis of 3-deoxyschweinfurthin B (3dSB)}

3.10.1 The Neighbors et al. approach (2005). Neighbors et al. reported the first synthesis of $3 \mathrm{dSB}$ (19) while targeting the synthesis of a natural product, schweinfurthin B. ${ }^{46}$ The regioselective dihydroxylation on the terminal olefin of compound 35 via Sharpless dihydroxylation gave the desired diol 135 in 68\% yield with $83 \%$ ee. The $(S)$ configuration was assigned to the new asymmetric centre in diol 135, which was confirmed by treating it with the $(S)$ - and $(R)$-enantiomers of $O$-methylmandelic acid under standard mixed anhydride coupling conditions, followed by spectroscopic studies. The diol 135 was transformed to nonracemic epoxide 136, as depicted in Scheme 18, in 75\% yield, followed by deprotection of TBS using TBAF to afford 137. Furthermore, acid-catalysed cyclisation gave the expected tricyclic core 49 in $38 \%$ yield, which upon benzylic oxidation using $\mathrm{MnO}_{2}$ gave aldehyde 50a. The HWE olefination reaction between phosphonate ester 86 and aldehyde 50a yielded protected $(E)$-stilbene 138 and deprotection with camphorsulfonic acid (CSA) afforded 3dSB (19) in 77\% yield (Scheme 18).

3.10.2 Mente et al. approach (2008). Mente et al. synthesized 3dSB (19) using an alternative route similar to that of 3dSA (Scheme 18). ${ }^{52}$ Phosphonate ester 132 and MOM-protected geranyl aldehyde 133 were condensed using an HWE olefination to give $(E)$-stilbene 139, which was deprotected under acidic conditions to yield 3dSB (19) in 81\% yield (Scheme 19).

\subsection{Synthesis of $(+)$-vedelianin (2011)}

Topczewski et al. reported the synthesis of (+)-vedelianin (20) using a synthetic route similar to that of schweinfurthin A. A MOM-protected aldehyde 78 was synthesized from 101 via Shi epoxidation and $\mathrm{a} \mathrm{BF}_{3} \cdot \mathrm{OEt}_{2}$-mediated cyclisation. The $\mathrm{HWE}$ olefination of phosphonate ester 108 with aldehyde 78 selectively yielded $(E)$-stilbene 141, which upon MOM-deprotection afforded (+)-vedelianin (20) (Scheme 20). ${ }^{67}$

\section{Biological activities}

Schweinfurthins have shown a wide range of bioactivities, such as anticancer, antimicrobial, cytotoxicity and radical scavenging effects. However, the focus has always been on their anticancer properties, since they have displayed excellent inhibition of the growth of human cancer cell lines in the National Cancer Institute's 60-cell line screen (NCI-60).

\subsection{Anticancer activity}

The cytotoxicity of schweinfurthins towards cancer cell lines was first reported by Beutler et al. when they isolated three novel geranyl stilbenes, schweinfurthins A (1), B (2), and C (3). ${ }^{27}$ Schweinfurthins A (1) and B (2) were evaluated in an in vitro experiment using the lung cancer-derived A549 and glioblastoma multiforme (GBM)-derived SF295 cell lines. A 1 hour

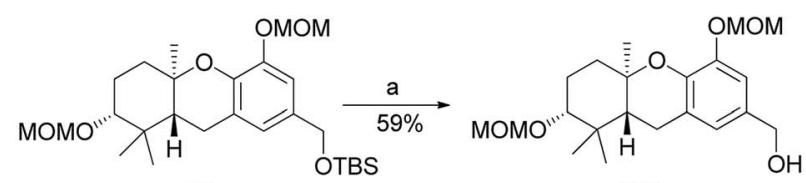

56

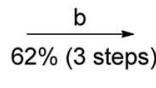

131<smiles>CCOP(=O)(Cc1cc2c(c(OC)c1)O[C@]1(C)CC[C@H](OC)C(C)(C)[C@@H]1C2)OCC</smiles>

132


3dSA

Scheme 17 Synthesis of 3-deoxyschweinfurthin A (3dSA) by Mente et al. ${ }^{52}$ Reagents and conditions: (a) TBAF, THF, 4 h; (b) (1) MsCl, NEt 3 , $\mathrm{CH}_{2} \mathrm{Cl}_{2}$; (2) Nal, acetone, $15 \mathrm{~h}$; (3) $\mathrm{P}(\mathrm{OEt})_{3}, 80^{\circ} \mathrm{C}, 7 \mathrm{~h}$; (c) NaH, geranyl aldehyde 133, 15-crown-5, THF, $16 \mathrm{~h}$; (d) $\mathrm{p}$ - $\mathrm{TsOH}, \mathrm{MeOH}$. 
<smiles>COc1cc(CO[Sb])cc(C/C=C(\C)CCC2OC2(C)C)c1OCC(C)(C)C</smiles>

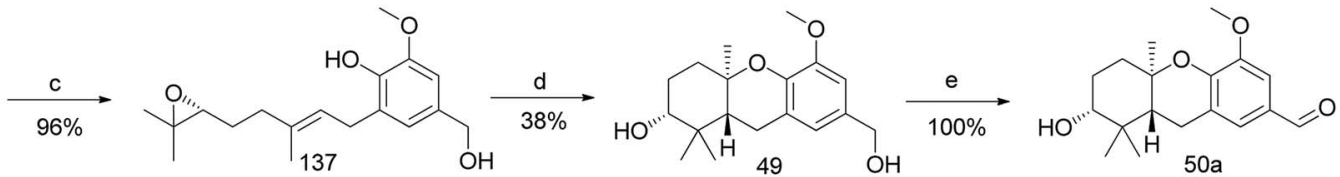<smiles>COc1cc(/C=C/c2cc3c(c(OC)c2)O[C@@]2(C)CC[C@@H](O)C(C)(C)[C@]2(C)C3)cc(OC)c1C/C=C(\C)CCC=C(C)C</smiles>

Scheme 18 Synthesis of 3-deoxyschweinfurthin B (3dSB) by Neighbors et al. ${ }^{46}$ Reagents and conditions: (a) AD-mix- $\alpha$ in $\mathrm{H}_{2} \mathrm{O} / t-\mathrm{BuOH}, \mathrm{CH}{ }_{3}-$ $\mathrm{SO}_{2} \mathrm{NH}_{2}, 6{ }^{\circ} \mathrm{C}, 15 \mathrm{~h}$; (b) (1) $\mathrm{MsCl}, \mathrm{NEt}_{3}, \mathrm{CH}_{2} \mathrm{Cl}_{2}, 2 \mathrm{~h}$; (2) $\mathrm{K}_{2} \mathrm{CO}_{3}, \mathrm{MeOH}, 20 \mathrm{~h}$; (c) TBAF, THF, $1.5 \mathrm{~h}$; (d) $\mathrm{TFA} \mathrm{CH}_{2} \mathrm{Cl}_{2}, 2$ h; (e) $\mathrm{MnO}_{2}, \mathrm{CH}_{2} \mathrm{Cl}_{2}$; (f) phosphonate ester 86, NaH, THF, 18 h; (g) $\mathrm{CSA}, \mathrm{MeOH}, 5$ h.

treatment led to negligible cytotoxicity, whereas evaluation at 48 hours showed modest cytotoxicity for each compound (Table 2). However, schweinfurthin $\mathrm{C}$ was found to be biologically inactive.

The SF295 cell line was found to be the most sensitive for compound 1 , with a growth inhibition $\left(\mathrm{GI}_{50}\right)$ of $11 \mathrm{nM}$ and total growth inhibition (TGI) of $52 \mathrm{nM} \cdot{ }^{27}$ Schweinfurthin A is a potent member of this family that inhibits the SF295 line at a low nanomolar concentration and displays 1000-fold selectivity compared to that of the A549 cell line; however, its mechanism of action has not been fully elucidated.

GBM is the most common, deadly brain tumor in adults, which is highly infiltrative, resistant to chemotherapy and incurable. Previous studies have shown that neurofibromatosis type 1 (NF1), an autosomal dominant genetic disorder, plays a role in GBM tumorigenesis. ${ }^{\mathbf{6 8 , 6 9}}$ Turbyville et al. studied the mode of action of schweinfurthin $\mathrm{A}$ and observed that it inhibited SF295 and KR158 cell lines in a dose-dependent manner with no effect on A549, indicating that schweinfurthin A acts via a cytotoxic mechanism rather than a cytostatic one. Further findings have indicated that schweinfurthin A does not act at the level of Ras inhibition, but selectively inhibits proliferation and Rho signalling in the glioma and NF1 tumor cells in an NF1-GRD-dependent manner. ${ }^{70}$

Beutler et al. performed a 2 day cytotoxicity assay on schweinfurthin D (4) using two cell lines, SF295 and A549. Schweinfurthin D (4) ( $\left.\mathrm{IC}_{50} 3.44 \mathrm{nM}\right)$ was found to be equipotent to schweinfurthin $\mathrm{B}(2)\left(\mathrm{IC}_{50} 5.33 \mathrm{nM}\right)$ for the SF295 line whereas, for the A549 cell line, the $\mathrm{IC}_{50}$ for compounds 4 and 2 were $4.82 \mu \mathrm{M}$ and $9.77 \mu \mathrm{M}$, respectively. ${ }^{28}$

Mente et al. tested both the enantiomers of schweinfurthin $\mathrm{F}$ (6a and 6b) for growth inhibition in RPMI-8226 human-derived myeloma cells using a $3 \mathrm{H}$-thymidine incorporation assay of DNA synthesis. ${ }^{58}$ The enantiomers $\mathbf{6 a}$ and $\mathbf{6 b}$ exhibited an $\mathrm{IC}_{50}$ of $0.58 \mu \mathrm{M}$ and $3.40 \mu \mathrm{M}$, respectively (Table 3). In a gliomaderived SNB 75 cell line, a large divergence of bioactivity was observed, where compound 6 a displayed a $\mathrm{GI}_{50}$ of $10 \mathrm{nM}$ and its enantiomer $6 \mathbf{b}$ had a $\mathrm{GI}_{50}$ of $1.7 \mu \mathrm{M}$. The activity pattern was reversed in the malignant glioblastoma-derived human cell line U251, where $6 \mathbf{b}$ showed very high activity with a $\mathrm{GI}_{50}$ of $<10 \mathrm{nM}$, while $6 \mathrm{a}$ had a $\mathrm{GI}_{50}$ of $13 \mu \mathrm{M}$ (Table 3).58

Yoder $e t$ al. evaluated the cytotoxicity of schweinfurthins $\mathrm{E}-\mathrm{H}$ and a congener vedelianin against the A2780 ovarian cancer cell line (Table 4). ${ }^{29}$ Vedelianin (20) was found to be the most potent

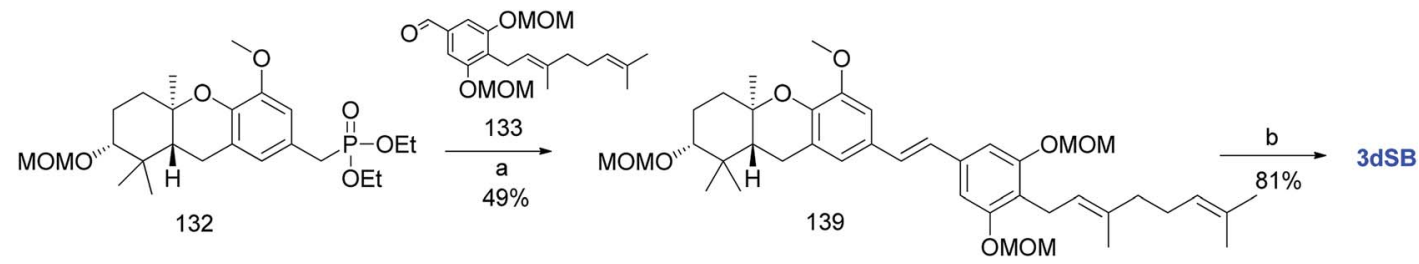

Scheme 19 Synthesis of 3-deoxyschweinfurthin B (3dSB) by Mente et al. ${ }^{52}$ Reagents and conditions: (a) NaH, geranyl aldehyde, 133, 15-crown-5, $\mathrm{THF}, 16 \mathrm{~h}$; (b) $p-\mathrm{TsOH}, \mathrm{MeOH}$ 
<smiles>CC#CCCC</smiles><smiles>COCc1cc2c(c(OC)c1)O[C@]1(C)CC[C@H](OC)C(C)C1C2</smiles><smiles>C#CC</smiles><smiles>COc1cc(C=O)cc2c1O[C@H]1C[C@H](OC)[C@@H](OC)[C@H](C)[C@H]1C[C@H]2C</smiles>

78

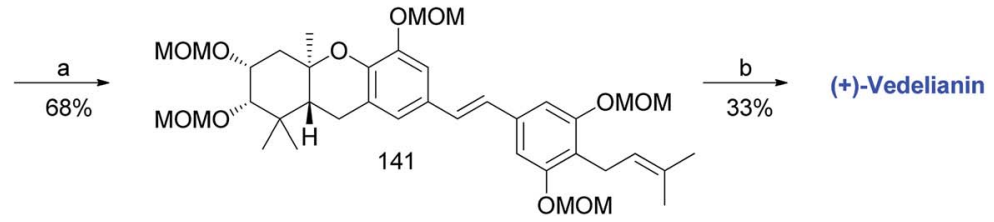

Scheme 20 Synthesis of (+)-vedelianin (2011) by Topczewski et al. ${ }^{67}$ Reagents and conditions: (a) KHMDS, phosphonate ester 108, THF, 30 min; (b) $p-\mathrm{TsOH}, \mathrm{MeOH}, 48 \mathrm{~h}$.

Table 2 Cytotoxicity of schweinfurthins A (1) and B (2) on SF295 and A549 cell lines

\begin{tabular}{lllll}
\hline Compound & $\mathbf{1}, \mathrm{IC}_{50}(\mu \mathrm{M})$ & & $2, \mathrm{IC}_{50}(\mu \mathrm{M})$ & \\
Protocol & $\mathrm{A} 549$ & $\mathrm{SF} 295$ & $\mathrm{~A} 549$ & $\mathrm{SF} 295$ \\
$1 \mathrm{~h}$ & 78.3 & 85.6 & $>170$ & $>170$ \\
$1 \mathrm{~h}$ washout & 36.4 & 0.109 & 142.1 & 5.1 \\
$48 \mathrm{~h}$ & 6.7 & $<0.00002$ & 12.6 & 0.016
\end{tabular}

compound with an $\mathrm{IC}_{50}$ of $0.13 \mu \mathrm{M}$. In a comparison of their cytotoxicity, vedelianin (20) was found to be twice as potent as schweinfurthin $\mathrm{E}(5)\left(\mathrm{IC}_{50} 0.26 \mu \mathrm{M}\right)$ and three times as potent as schweinfurthin $\mathrm{G}(7)\left(\mathrm{IC}_{50} 0.39 \mu \mathrm{M}\right)$.

Péresse et al. evaluated the cytotoxicity of schweinfurthins G, $\mathrm{K}-\mathrm{Q}$, and vedelianin against GBM-derived U87 and lung cancerderived A549 cells (Table 5). ${ }^{31}$ All of the compounds showed good to moderate cytotoxicity on the U87 cell line, except for schweinfurthin P (16). As expected, schweinfurthins G (7), Q (17), and vedelianin (20) containing the hexahydroxanthene moiety, were found to be highly cytotoxic with an $\mathrm{EC}_{50}$ of 0.04 , 0.05 , and $0.03 \mu \mathrm{M}$, respectively on the U87 cell line. However, on the A549 cell line, only schweinfurthins G (7), K (11), and L (12) and vedelianin (20) were found to be active, exhibiting cytotoxicity in the sub-micromolar range. ${ }^{31}$

The schweinfurthin family has been found to strongly inhibit the growth of human cancer cell lines when evaluated in the NCI 60-cell line screen. The mean $\mathrm{GI}_{50}$ values of the schweinfurthins are shown in Table 6. Schweinfurthin A (1), one of the potent compounds in this family, displayed a mean $\mathrm{GI}_{50}$ of $0.36 \mu \mathrm{M}$, whereas schweinfurthin B (2) was found to have

Table 3 Cytotoxicity of schweinfurthin $F(6 a)$ and its enantiomer (6b) on RPMI-8226, SNB 75, and U251 cell lines

\section{Compounds}

\begin{tabular}{lll} 
Cell line & 6a & 6b \\
\hline RPMI-8226 & $\mathrm{IC}_{50}=0.58 \mu \mathrm{M}$ & $\mathrm{IC}_{50}=3.40 \mu \mathrm{M}$ \\
SNB 75 & $\mathrm{GI}_{50}=10 \mathrm{nM}$ & $\mathrm{GI}_{50}=1.7 \mu \mathrm{M}$ \\
U251 & $\mathrm{GI}_{50}=13 \mu \mathrm{M}$ & $\mathrm{GI}_{50}<10 \mathrm{nM}$
\end{tabular}

a mean $\mathrm{GI}_{50}$ of $0.81 \mu \mathrm{M} .{ }^{27}$ Schweinfurthin E (5) was found to be slightly more potent than compounds 1 and 2, with a mean $\mathrm{GI}_{50}$ of $0.19 \mu \mathrm{M} .^{29}$ The two enantiomers of schweinfurthin $\mathrm{F}, \mathbf{6 a}$ and 6b were found to have a mean $\mathrm{GI}_{50}$ of 0.41 and $0.13 \mu \mathrm{M}$, respectively (Table 6). ${ }^{58}$

Schweinfurthin I (9) was observed to be the least potent compound with a mean $\mathrm{GI}_{50}$ of $10 \mu \mathrm{M}$, whereas schweinfurthin J (10) exhibited moderate growth inhibitory activity with a mean $\mathrm{GI}_{50}$ of $2.8 \mu \mathrm{M}^{30}$ The synthetic analogue of schweinfurthin B, 3dSB (19) was found to have a mean $\mathrm{GI}_{50}$ of $0.21 \mu \mathrm{M}^{46}$ Vedelianin (20) was the most potent compound, which exhibited a mean $\mathrm{GI}_{50}$ of $0.08 \mu \mathrm{M}$ (Table 6).$^{58,67}$ The results suggest that the presence of dihydroxy groups on the A-ring of the tricyclic hexahydroxanthene core [schweinfurthins A (1), B (2), and E (5) and vedelianin (20)] may be critical for inhibitory activity. Additionally, the mean $\mathrm{GI}_{50}$ values of schweinfurthin E (5) and vedelianin (20) indicated that a shorter prenyl side chain could enhance the inhibitory activity (Table 6).

\subsection{Free radical scavenging activity}

A high level of free radicals in living systems causes adverse effects that can lead to tissue damage, neural disorders, skin irritation, inflammation, cell death or various diseases, including cancer. ${ }^{71}$ The harmful effects caused by free radicals are counteracted by antioxidants, either from natural sources in the form of food or synthetic antioxidants. ${ }^{72-74}$ Petrova et al. evaluated the free radical scavenging activity of schweinfurthins A (1) and B (2) against DPPH radicals, but they were found to be less active than other extracted lignans (Table 7$){ }^{75}$

\subsection{Antimicrobial activity}

Natural products have particularly shown a protective role against microbial invasion. Petrova et al. tested schweinfurthins A (1) and B (2) for antibacterial activity against Staphylococcus aureus, and both 1 and $\mathbf{2}$ demonstrated antimicrobial activity, as shown in Table 8 . However, they were not active against Candida albicans and Escherichia coli. ${ }^{75}$ 
Table 4 Cytotoxicity of schweinfurthins $\mathrm{E}-\mathrm{H}$ and vedelianin on A2780 cells

\begin{tabular}{ll}
\hline Compound & $\mathrm{IC}_{50}(\mu \mathrm{M})$ \\
\hline $\mathbf{5}$ & \\
$\mathbf{6 a}$ & 0.26 \\
7 & 5.0 \\
$\mathbf{8}$ & 0.39 \\
$\mathbf{2 0}$ & 4.5 \\
&
\end{tabular}

\subsection{Pleiotropic effects of 3-deoxyschweinfurthin on isoprenoid homeostasis}

Holstein et al. studied the pleiotropic effects of a synthetic schweinfurthin, 3dSB (18), on isoprenoid homeostasis to determine whether 3dSB-induced cytotoxicity could be

Table 5 Cytotoxicity of schweinfurthins $G, K-Q$, and vedelianin on the GBM (U87) and lung cancer (A549) cell lines

\begin{tabular}{lll}
\hline Compound & $\mathrm{U}^{2}, \mathrm{EC}_{50}(\mu \mathrm{M})$ & $\mathrm{A} 549, \mathrm{EC}_{50}(\mu \mathrm{M})$ \\
\hline $\mathbf{1 1}$ & $0.25 \pm 0.08$ & $0.73 \pm 0.01$ \\
$\mathbf{1 2}$ & $0.45 \pm 0.03$ & $0.24 \pm 0.12$ \\
$\mathbf{1 3}$ & $0.50 \pm 0.04$ & $>10$ \\
$\mathbf{1 4}$ & $0.10 \pm 0.01$ & $>10$ \\
$\mathbf{1 5}$ & $0.025 \pm 0.006$ & $>10$ \\
$\mathbf{1 6}$ & $>10$ & $>10$ \\
$\mathbf{1 7}$ & $0.050 \pm 0.003$ & $>10$ \\
7 & $0.045 \pm 0.005$ & $0.80 \pm 0.04$ \\
$\mathbf{2 0}$ & $0.030 \pm 0.009$ & $0.190 \pm 0.002$ \\
Monomethyl auristatin E & $0.00020 \pm 0.00003$ & $0.00050 \pm 0.00005$
\end{tabular}

Table 6 Growth inhibition activity of schweinfurthins in the $\mathrm{NCl} 60$ cell line screen

\begin{tabular}{lll}
\hline Compounds & Mean $\mathrm{GI}_{50}(\mu \mathrm{M})$ & References \\
\hline $\mathbf{1}$ & 0.36 & 27 \\
$\mathbf{2}$ & 0.81 & 27 \\
$\mathbf{5}$ & 0.19 & 29 \\
$\mathbf{6 a}$ & 0.41 & 58 \\
$\mathbf{6 b}$ & 0.13 & 58 \\
$\mathbf{9}$ & 10 & 30 \\
$\mathbf{1 0}$ & 2.8 & 30 \\
$\mathbf{1 9}$ & 0.21 & 46 \\
$\mathbf{2 0}$ & 0.08 & 58 and 67
\end{tabular}

Table 7 Free radical scavenging activity of schweinfurthins $A$ (1) and $B(2)$

\begin{tabular}{lc}
\hline Compound & $\begin{array}{l}\mathrm{DPPH}^{a} \text { free radical } \\
\text { scavenging activity, \% inhibition }\end{array}$ \\
\hline 1 & $25.4 \pm 0.7$ \\
2 & $15.6 \pm 0.4$ \\
Caffeic acid $^{c}$ & $65.5 \pm 0.1$ \\
${ }^{a}{\text { DPPH solution } 0.02 \% \text { in EtOH. }^{b} \text { Mean value of three measurements } \pm}^{-1}$ S.D. ${ }^{c}$ Solution $0.21 \mathrm{mg} \mathrm{ml}^{-1}$ in ethanol.
\end{tabular}

Table 8 Antimicrobial activity of schweinfurthins A (1) and B (2) against S. aureus (at $400 \mu \mathrm{g}$ in the cup) ${ }^{a}$

\begin{tabular}{lc}
\hline Compound & $\begin{array}{l}\text { Zone of inhibition } \\
(\mathrm{mm})\end{array}$ \\
\hline $\mathbf{1}$ & $19 \pm 1$ \\
2 & $19 \pm 1$ \\
Streptomycin $^{b}$ & $30 \pm 1$ \\
$\begin{array}{l}a \\
\text { Tests were done in triplicate, values are mean } \pm \text { S.D. }{ }^{b} 100 \mu \mathrm{g} \text { in the } \\
\text { cup. }\end{array}$
\end{tabular}

prevented by co-incubation with an isoprenoid species. MTT assays to assess cell metabolic activity were performed by treating human multiple myeloma cell lines (RPMI-8226 and U266) with 3dSB and/or lovastatin in the presence or absence of mevalonate, farnesyl pyrophosphate (FPP) or geranylgeranyl pyrophosphate (GGPP). Cytotoxicity assays demonstrated that 3dSB had a synergistic interaction with lovastatin but not with other isoprenoid biosynthetic pathway (IBP) inhibitors in diverse human cancer cell lines. 3dSB enhanced the lovastatininduced decrease in protein prenylation. Additionally, intracellular FPP and GGPP levels were decreased in both established cell lines and primary cells. Holstein et al. reported that $3 \mathrm{dSB}$ alters isoprenoid levels and controls IBP and sterol homeostasis by disrupting multiple aspects of the regulatory elements. $^{76}$

\section{Conclusion}

Schweinfurthins display multiple biological and pharmacological activities. In particular, schweinfurthins possessing hexahydroxanthene have exhibited potent growth inhibitory activity in NCI 60-cell cancer screening. The synthesis of hexahydroxanthene has smoothed the path towards exploring these natural products and carrying out diverse structureactivity relationship studies. Further investment in optimization by preparing new synthetic schweinfurthin analogues that are metabolically stable, potent and specific may enhance the drug discovery process. The Macaranga species will continue to be investigated in the future due to the anticancer activity of the schweinfurthins and their congeners. In the present review, we have mainly focused on the synthesis and biological activities of the schweinfurthins. We expect that the information provided in this review might be helpful for the synthesis of schweinfurthin analogues and may offer a platform upon which to develop useful therapeutic candidates.

\section{Conflicts of interest}

There are no conflicts to declare.

\section{Abbreviations}

TBAI Tetrabutylammonium iodide $m$-CPBA $m$-Chloroperoxybenzoic acid 
MOM Methoxymethyl

TBS tert-Butyldimethylsilyl

TBAF Tetrabutylammonium fluoride

TFA Trifluoroacetic acid

NMR Nuclear magnetic resonance

TMEDA Tetramethylethylenediamine

BOM Benzyloxymethyl

DDQ 2,3-Dichloro-5,6-dicyano-1,4-benzoquinone

KHMDS Potassium bis(trimethylsilyl)amide

NOESY Nuclear Overhauser effect spectroscopy

PDC Pyridinium dichromate

NCI60 National Cancer Institute; 60 human tumor cell line

$\mathrm{GI}_{50} \quad$ Concentration of compound required to inhibit growth by $50 \%$

TGI Concentration of compound required for the total inhibition of growth

IC $_{50}$ Concentration of compound required to inhibit by $50 \%$

$\mathrm{EC}_{50}$ Concentration of a compound expected to produce an effect in $50 \%$ of test organisms

DPPH 2,2-diphenyl-1-picrylhydrazyl

\section{Acknowledgements}

This work was supported by the National Research Foundation of Korea (NRF), grant funded by the Korea government (MSIT) (No. 2012M3A9C1053532 and 2015M3A6A4065734).

\section{References}

1 M. S. Butler, J. Nat. Prod., 2004, 67, 2141.

2 M. S. Butler, Nat. Prod. Rep., 2005, 22, 162.

3 B. Shen, Cell, 2015, 163, 1297.

4 M. Dong, B. Pfeiffer and K. Altmann, Drug Discovery Today, 2017, 22, 585.

5 T. Shen, X. Wang and H. Lou, Nat. Prod. Rep., 2009, 26, 916.

6 Z. I. Chrząścik, Crit. Rev. Anal. Chem., 2009, 39, 70.

7 S. Fulda, Drug Discovery Today, 2010, 15, 757.

8 L. Carter, J. D'Orazio and K. J. Pearson, Endocr.-Relat. Cancer, 2014, 21, R209.

9 B. Aggarwal, A. Bhardwaj, R. Aggarwal, N. Seeram, S. Shishodia and Y. Takada, Anticancer Res., 2004, 24, 2783. 10 Z. A. Bishayee, Cancer Prev. Res., 2009, 2, 409.

11 M. Jang, L. Cai, G. Udeani, K. Slowing, C. Thomas, C. Beecher, H. Fong, N. Farnsworth, A. Kinghorn, R. Mehta, R. Moon and J. M. Pezzuto, Science, 1997, 275, 218.

12 L. Stivala, M. Savio, F. Carafoli, P. Perucca, L. Bianchi, G. Maga, L. Forti, U. Pagnoni, A. Albini, E. Prosperi and V. Vannini, J. Biol. Chem., 2001, 276, 22586.

13 H. Piotrowska, M. Kucinska and M. Murias, Mutat. Res., 2012, 750, 60.

14 M. Nalli, G. Ortar, A. Moriello, E. Morera, V. Marzo and L. Petrocellis, Bioorg. Med. Chem. Lett., 2016, 26, 899.

15 R. Mikstacka, T. Stefański and J. Różański, Cell. Mol. Biol. Lett., 2013, 18, 368.
16 J. Sirerol, M. Rodríguez, S. Mena, M. Asensi and A. Ortega, Oxid. Med. Cell. Longevity, 2016, 3128951.

17 R. Mikstacka, A. Rimando, K. Szalaty, K. Stasik and W. Dubowska, Xenobiotica, 2006, 36, 269.

18 G. Belofsky, A. French, D. Wallace and S. Dodson, J. Nat. Prod., 2004, 67, 26.

19 M. Liu, Y. Han, D. Xing, Y. Shi, L. Xu, L. Du and Y. Ding, J. Asian Nat. Prod. Res., 2004, 6, 229.

20 Q. Hu, B. Zhou, Y. Ye, Z. Jiang, X. Huang, Y. Li, G. Du, G. Yang and X. M. Gao, J. Nat. Prod., 2013, 76, 1854.

21 J. Ingle, D. Ahmann, S. Green, J. Edmonson, H. Bisel, L. Kvols, W. Nichols, E. Creagan, R. Hahn, J. Rubin and S. Frytak, N. Engl. J. Med., 1981, 304, 16.

22 Z. A. Herbst, H. Ulfelder and D. Poskanzer, N. Engl. J. Med., 1971, 284, 878.

23 V. Jordan, Br. J. Pharmacol., 2006, 147, S269.

24 Z. A. Howell, J. Cuzick, M. Baum, A. Buzdar, M. Dowsett, J. Forbes, G. Hoctin-Boes, J. Houghton, G. Locker and J. Tobias, Lancet, 2005, 365, 60.

25 E. Bommel, T. Hendriksz, A. Huiskes and A. G. Zeegers, Ann. Intern. Med., 2006, 144, 101.

26 G. Webster, Ann. Mo. Bot. Gard., 1994, 81, 33.

27 J. Beutler, R. Shoemaker, T. Johnson and M. Boyd, J. Nat. Prod., 1998, 61, 1509.

28 J. Beutler, J. Jato, G. Cragg and M. Boyd, Nat. Prod. Lett., 2000, 14, 399.

29 B. Yoder, S. Cao, A. Norris, J. Miller, F. Ratovoson, J. Razafitsalama, R. Andriantsiferana, V. Rasamison and D. Kingston, J. Nat. Prod., 2007, 70, 342.

30 P. Klausmeyer, Q. Van, J. Jato, T. McCloud and J. Beutler, J. Nat. Prod., 2010, 73, 479.

31 T. Péresse, G. Jézéquel, P. Allard, V. Pham, D. Huong, F. Blanchard, J. Bignon, H. Lévaique, J. Wolfender, M. Litaudon and F. Roussi, J. Nat. Prod., 2017, 80, 2684.

32 O. Thoison, E. Hnawia, F. Gueritte-voegelein and T. Sevenet, Phytochemistry, 1992, 31, 1439.

33 E. Hnawia, O. Thoison, F. Guéritte-Voegelein, D. Bourret and T. Sévenet, Phytochemistry, 1990, 29, 2367.

34 B. Schutz, A. Wright, T. Rali and O. Sticher, Phytochemistry, 1995, 40, 1273.

35 S. Sultana and M. Ilyas, Phytochemistry, 1986, 25, 953.

36 W. Hui, K. Ng, N. Fukamiya, M. Koreeda and K. Nakanishi, Phytochemistry, 1971, 10, 1617.

37 R. Mechoulam and B. Yagen, Tetrahedron Lett., 1969, 10, 5349.

38 G. Manners, L. Jurd and K. Stevens, Tetrahedron, 1972, 28, 2949.

39 G. Trammell, Tetrahedron Lett., 1978, 19, 1525.

40 E. Treadwell, J. Neighbors and D. Wiemer, Org. Lett., 2002, 4, 3639.

41 B. Branchaud and H. Blanchette, Tetrahedron Lett., 2002, 43, 351.

42 Z. A. Toshimitsu, C. Hirosawa and K. Tamao, Synlett, 1996, 465.

43 T. Kametani, K. Suzuki, H. Kurobe and H. Nemoto, J. Chem. Soc., Chem. Commun., 1979, 1128. 
44 T. Kametani, H. Kurobe, H. Nemoto and K. Fukumoto, J. Chem. Soc., Perkin Trans. 1, 1982, 1085.

45 D. Boger and I. Jacobson, J. Org. Chem., 1991, 56, 2115.

46 J. Neighbors, J. Beutler and D. Wiemer, J. Org. Chem., 2005, 70, 925.

47 J. Neighbors, N. Mente, K. Boss, D. Zehnder and D. Wiemer, Tetrahedron Lett., 2008, 49, 516.

48 Z. Wang and Y. Shi, J. Org. Chem., 1998, 63, 3099.

49 L. Shu and Y. Shi, Tetrahedron Lett., 1999, 40, 8721.

50 J. Topczewski, J. Kodet and D. Wiemer, J. Org. Chem., 2011, 76, 909.

51 J. Topczewski, M. Callahan, J. Neighbors and D. Wiemer, J. Am. Chem. Soc., 2009, 131, 14630.

52 N. Mente, J. Neighbors and D. Wiemer, J. Org. Chem., 2008, 73, 7963.

53 E. Treadwell, S. Cermak and D. Wiemer, J. Org. Chem., 1999, 64, 8718.

54 J. Topczewski, J. Neighbors and D. Wiemer, J. Org. Chem., 2009, 74, 6965.

55 J. Stafford and N. Valvano, J. Org. Chem., 1994, 59, 4346.

56 P. Manchand, P. Belica and H. S. Wong, Synth. Commun., 1990, 20, 2659.

57 R. Lange, J. Org. Chem., 1962, 27, 2037.

58 N. Mente, A. Wiemer, J. Neighbors, J. Beutler, R. Hohl and D. Wiemer, Bioorg. Med. Chem. Lett., 2007, 17, 911.

59 J. Neighbors, M. Salnikova and D. Wiemer, Tetrahedron Lett., 2005, 46, 1321.

60 N. Yee and R. Coates, J. Org. Chem., 1992, 57, 4598.

61 E. Corey and K. Liu, J. Am. Chem. Soc., 1997, 119, 9929.
62 E. Corey and M. Sodeoka, Tetrahedron Lett., 1991, 32, 7005. 63 J. Zhang and E. Corey, Org. Lett., 2001, 3, 3215.

64 S. Taylor, M. Ivanovic, L. Simons and M. Davis, Tetrahedron: Asymmetry, 2003, 14, 743.

65 M. Singh and N. P. Argade, Synthesis, 2012, 44, 2895.

66 B. Wang, Y. Zhang, J. Chen, W. Zhang, J. Song, B. Del, L. Brown and G. Miller, PCT Int. Appl., CODEN: PIXXD2 WO 2003009807 A220030206 CAN 138:153318 AN 2003:97274, 2003.

67 J. Topczewski and D. Wiemer, Tetrahedron Lett., 2011, 52, 1628.

68 K. Reilly, D. Loisel, R. Bronson, M. McLaughlin and T. Jacks, Nat. Genet., 2000, 26, 109.

69 Y. Zhu, F. Guignard, D. Zhao, L. Liu, D. Burns, R. Mason, A. Messing and L. Parada, Cancer Cell, 2005, 8, 119.

70 T. Turbyville, D. Gürsel, R. Tuskan, J. Walrath, C. Lipschultz, S. Lockett, D. Wiemer, J. Beutler and K. Reilly, Mol. Cancer Ther., 2010, 9, 1234.

71 I. Gulcin, Chem.-Biol. Interact., 2009, 179, 71.

72 S. Kedare and R. Singh, J. Food Sci. Technol., 2011, 48, 412.

73 E. Koksal and I. Gulcin, Turk. J. Agric. For., 2008, 32, 65.

74 T. Kulisic, A. Radonic, V. Katalinic and M. Milos, Food Chem., 2004, 85, 633.

75 Z. A. Petrova, M. Popova, C. Kuzmanova, I. Tsvetkova, H. Naydenski, E. Muli and V. Bankova, Fitoterapia, 2010, 81, 509.

76 S. Holstein, C. Kuder, H. Tong and R. Hohl, Lipids, 2011, 46, 907. 